\title{
Palaeomagnetism and magnetostratigraphy of the Permian and Triassic of Spitsbergen: a review of progress and challenges
}

Mark W. Hounslow ${ }^{1} \&$ Jerzy Nawrocki ${ }^{2}$

${ }^{1}$ Centre for Environmental Magnetism and Palaeomagnetism, Geography Dept., Lancaster

Environment Centre, Lancaster University, Bailrigg, Lancaster LA1 4YB, UK

${ }^{2}$ Palaeomagnetic Laboratory, Polish Geological Institute, Rakowiecka 4, PL-00-975 Warsaw, Poland.

Correspondence: Mark W. Hounslow, Centre for Environmental Magnetism and Palaeomagnetism, Geography Dept., Lancaster Environment Centre, Lancaster University, Bailrigg, Lancaster LA1 4YB, UK. E-mail: m.hounslow@lancs.ac.uk.

\begin{abstract}
Permian and Triassic sediments from Svalbard provide a testing ground for evaluating concepts about the polarity and configuration of the geomagnetic field during the Palaeozoic-Mesozoic transition. This review examines existing palaeomagnetic and magnetostratigraphic data and also reexamines the issue of partial remagnetization of these sediments. Permian and Triassic palaeomagnetic poles from Spitsbergen demonstrate a close similarity to the stable-Europe apparent polar wander path. Magnetostratigraphy from the Gipsdalen and Tempelfjorden groups demonstrates the dominance of reverse polarity (the Permo-Carboniferous Reverse Superchron), with evidence for three short-duration normal magnetozones, one of which may provide a useful marker near the base of the Permian. The other two normal magnetozones in the middle and lower parts of the Kapp Starostin Formation most likely represent equivalent magnetozones in the Wordian and Capitanian (mid Permian). Magnetostratigraphy of the Lower Triassic to lowest parts of the Upper Triassic in central and western Spitsbergen provides greater chronostratigraphic detail than hitherto available from biostratigraphy alone. This demonstrates the scale of a number of suspected hiatuses, and also hints at improved chronostratigraphic correlations between east and west Spitsbergen. Upper Triassic sediments provide the best palaeomagnetic properties, indicating that future magnetostratigraphic studies in this interval may improve chronostratigraphic understanding of this poorly dated interval. A persistent partial remagnetization affecting both Permian and Triassic sediments is not of one origin. It may be both a Brunhes-age viscous remanence and a Palaeogene heating/burial induced magnetization, or a fluid-flow related remagnetization locally in western Spitsbergen. The remagnetization is often composite (Cenozoic plus older) in nature.
\end{abstract}




\section{Introduction}

In addition to the drawback of their remote location, the Permian and Triassic rocks of Svalbard do not provide ideal and "classic" lithologies, such as volcanic and igneous rocks, pelagic limestones and red beds, for palaeomagnetic study. These are the main reasons these rocks have been overlooked for palaeomagnetic study until relatively recently. Nevertheless, the Permian and Triassic of Svalbard provide a potential testing ground for a number of significant issues in palaeomagnetism. First, they provide a largely undeformed marine sediment record through large parts of the Permian and Triassic (Mørk et al. 1992; Nakrem et al. 1992; Stemmerik 2000; Stemmerik \& Worsley 2005), in contrast to sizeable parts of the Permian and Triassic world at lower palaeolatitudes, which are often continental red beds, or marine successions later involved in orogenesis. As such, the Svalbard successions provide key sections for unraveling the details of the Earth's magnetic field polarity (i.e., magnetostratigraphy) through the Permian and Triassic. Second, recent debates about the non-dipole (octapole) content of the longer-term averaged geomagnetic field and its effect on apparent polar wander paths (APWP), and resulting conflicts of plate reconstructions, have heavily used data from rocks of Permian-Triassic age (Van der Voo \& Torsvik 2001; Tauxe \& Kent 2004; Kent \& Tauxe 2005). These data are strongly biased to studies on rocks in low to mid-palaeolatitudes, whereas testing of long-term field models requires a spread of data through to high palaeolatitudes (Van der Voo \& Torsvik 2001, 2004). The relatively well-dated Permian and Triassic rocks of the Arctic therefore provide a potential testing ground for these concepts.

Palaeomagnetic study of the Permian and Triassic rocks of Svalbard (Fig. 1) has a relatively short history, with all the studies being restricted to Spitsbergen. Jeleńska (1987) and Vincenz \& Jeleńska (1984) were the first to attempt study of the Spitsbergen Permian sediments, followed by Nawrocki (1999). In the late 1980s to mid-1990s several studies by a group based in Bergen were the first to attempt palaeomagnetic investigation of various parts of the Svalbard Triassic; these findings remain unpublished. The first fully published works on the Triassic are those of Nawrocki (1999) and Nawrocki \& Grabowski (2000), along with a preliminary magnetostratigraphic summary of the Lower Triassic by Hounslow et al. (1996).

This review summarizes and evaluates published palaeomagnetic studies of the Permian-Triassic of Spitsbergen to gain an integrated view of the magnetic field behaviour during this interval. We also examine the issue of partial remagnetization of these rocks (which is a recurring theme in most studies), using existing data as well as some unpublished data relating to our own studies 
of these rocks. We have also transferred the older lithostratigraphic nomenclature used by some of these authors onto the newer lithostratigraphy of Dallman (1999).

\section{Geological setting}

The Permian and Triassic deposits of Svalbard (Fig. 1) are a part of the extensive deposits on the northern passive margin of Pangaea, stretching from north-eastern Siberia in the east, through the Novaya Zemlya region into the Barents Sea, and on into the Sverdrup Basin in northern Canada (Doré 1991; Mørk et al. 1992; Stemmerik 2000; Stemmerik \& Worsley 2005). The Permian and Triassic are largely marine rocks in Svalbard, although at other marginal locations on the northern Pangaean margin these interfinger with non-marine sediments (Mørk et al. 1992; Stemmerik 2000; Egorov \& Mørk 2000). In western Spitsbergen the combined Permian and Triassic is on the order of $1700 \mathrm{~m}$ thick, which in central Spitsbergen thins to about $1400 \mathrm{~m}$. The succession on Svalbard appears to represent most of the time-span through the Permian and Triassic, except for hiatus in parts of the mid-Permian, late Permian and several (mostly poorly understood) in the late Triassic (Fig. 2).

The Permian of Svalbard consists of limestones, dolomites and evaporites in the Gipsdalen Group, grading upwards into cherty limestones and silicified shales and siltstones in the Tempelfjorden Group (Fig. 2). In central Svalbard the Tempelfjorden Group often consists of sandy glauconitic and cherty limestones. The hiatus which characterizes the Permian-Triassic boundary and the late Permian is more extensive (i.e., into the Lower Triassic) in southern (e.g., Hornsund and Bellsund regions) and eastern Svalbard (i.e., Edgeøya), whereas in western and central Spitsbergen the correlated Permian-Triassic boundary (i.e., first occurrence of Hindeous parvus) is preserved in the base of the Vardebukta and Vikinghøgda formations (Wignall et al. 1997; Mørk, Dallmann et al. 1999; Mørk, Elvebakk et al. 1999; Hounslow et al. in press). The Lower and Middle Triassic consists of shales, siltstones and sandstones organized into repeated coarsening-up cycles. These are more pronounced in western Spitsbergen, whereas in central and eastern Svalbard the succession is dominated by shales, often with organic matter contents above $1 \%$ in the Spathian (late Olenekian) and Middle Triassic, along with phosphate rich intervals in the Ladinian (Mørk, Elvebakk et al. 1999; Krajewski 2000). The Carnian (lower part of Upper Triassic) on Svalbard (Tschermakfjellet and De Geerdalen formations; Fig. 2) displays a dramatic switch to an interval of deltaic and non-marine deposition. The Norian and last stage of the Triassic, the Rhaetian, is probably incomplete or highly condensed in comparison to the underlying parts of the Triassic and Permian (Fig. 2). 
The successions in western Spitsbergen are segmented by open folding and thrusting, the consequence of transpression during the Palaeocene-Eocene, associated with the initial opening of the North Atlantic between Greenland and Svalbard (Bergh \& Grogan 2003; Braathen et al. 1999), often leading to moderate to steep bedding dips. The Permian and Triassic in central Spitsbergen and the eastern Svalbard islands are largely unaffected by this deformation, commonly having bedding dips of less than $5^{\circ}$. Thermal maturation of organic matter shows the least heating of the Permian and Triassic in central and eastern Svalbard (Bjorøy et al. 1978; Bjorøy et al. 2007).

\section{Permian and Triassic palaeomagnetic poles}

Rowley \& Lottes (1988) initially considered Svalbard to be a separate microplate during the Mesozoic, in spite of earlier palaeomagnetic data from the Devonian and Early Carboniferous of Spitsbergen (Watts 1985; Torsvik et al. 1985; Jeleńska \& Lewandowski 1986), which fall close to the Baltica APWP. Other virtual geomagnetic pole (VGP) data from the late CarboniferousPermian poles isolated by Jeleńska (1987) and Vincenz \& Jeleńska (1985) appeared to deviate from that of the European APWP (Fig. 3a), which in addition had large directional uncertainty. Of these poles reported by Jeleńska \& Vincenz (1985), those from the Festningen/Bellsund sections, from the lower part of the Kapp Starostin and the Wordeikammen Formation (Fm.), show significant (at 95\% confidence) deviation from the Baltica APWP (Table 1). This deviation was originally explained as a result of the rotation of Spitsbergen in relation to Europe during the opening of the Labrador Sea and Greenland-Norwegian Sea (Jeleńska 1987). However, the newest Carboniferous-Permian-Triassic palaeomagnetic data from the Isfjorden area supports the hypothesis that Spitsbergen has been an integral part of the Laurussia plate since this time (Nawrocki 1999), which is fully supported by the vast amount of data now available from the Barents Sea stemming from hydrocarbon exploration. The limited VGP data from the Gipsdalen and Tempelfjorden groups (Table 1, Fig. 3) isolated from the Kapp Schoultz, Trygghamna and Kapp Wijk sections (Nawrocki 1999), are statistically indistinguishable from the Permian part of the Laurussia APWP (Fig. 3a, Table 1). A closer relationship to the Laurussia APWP is shown by most of the Triassic VGP data, except that from western Spitsbergen in the Trygghamna section (Fig. 3a, Table 1, pole ID 7).

Part of the apparent deviations from the APWP for the west Spitsbergen Permian-Triassic palaeopoles may relate to unrecognized vertical-axis rotations. Some results from western Spitsbergen clearly demonstrate some clockwise rotations of ca. $20-40^{\circ}$ (Nakazawa et al. 1990; Michalski \& Lewandowski 2004). However, the divergent Permian pole from the Lower part of 
the Kapp Starostin Fm. (pole ID 3 in Table 1; Jeleńska \& Vincenz 1985) cannot be explained by this mechanism because of its anomalously steep inclination. Similar small vertical-axis rotations may also relate to local tectonic detachments in central Spitsbergen (Hounslow, $\mathrm{Hu}$, Mørk, Vigran et al. 2007).

The Gipsdalen Group palaeomagnetic data of Nawrocki (1999) indicate that during this time, central Spitsbergen being a part of Laurussia, was located at about $27^{\circ} \mathrm{N}$ (Fig. 3b, Table 1). However, as has been suggested by Van der Voo \& Torsvik (2001; 2004), a precise location of the late Palaeozoic-Early Mesozoic palaeocontinents is subject to some $8^{\circ}$ of latitudinal displacement if a purely geocentric axial dipole field model is used. The causes of this displacement are either an octapole contribution to the geomagnetic field or persistent sedimentary inclination shallowing of the VGP data (Tauxe \& Kent 2004; Tauxe 2005). Palaeogeographic reconstructions using the Pangaea A-type configuration for the Lower Permian (Fig. 3b) indicate ca. $8^{\circ}$ of palaeolatitudinal difference between the projected location of Spitsbergen and the palaeomagnetic latitude obtained using the geocentric axial dipole hypothesis. Using these concepts, the refined palaeomagnetic data indicate that during the Lower Permian the true palaeolatitude of Spitsbergen was about $35^{\circ} \mathrm{N}$, changing to $45^{\circ} \mathrm{N}$ near the Permian-Triassic boundary and to about $55^{\circ} \mathrm{N}$ by the end of the Triassic.

The mineralogical origin of the magnetization in the Permian and Triassic rocks of Spitsbergen implicates magnetite or titanomagnetite as the most significant carrier, demonstrated by low temperature properties and thermal demagnetization of isothermal remanent magnetization (Nawrocki 1999; Hounslow; Hu, Mørk, Vigran et al. 2007). The Permian rocks displaying primary components often show maximum unblocking temperatures of $450-500{ }^{\circ} \mathrm{C}$ (Nawrocki 1999), largely disguised by thermal alteration at $420-440{ }^{\circ} \mathrm{C}$ or lower temperatures. In Triassic rocks the magnetization process is quite complex in character, as can be seen by the associations between lithology groups, natural remanent magnetization (NRM) intensity and magnetic susceptibility (Fig. 4). In the Lower and Middle Triassic, enhanced NRM intensities are often associated with calcite and dolomite concretions and beds, which could indicate either better preservation of the magnetite in these lithologies (i.e., possibly protected from late sulphide diagenesis) or perhaps larger amounts of other magnetic minerals (possibly magnetic sulphides). Most of the clastic lithologies have broadly similar NRM intensity and magnetic susceptibility, with values of NRM intensity often $<1 \mathrm{~mA} / \mathrm{m}$. The clastic units in the Upper Triassic (Fig. 4a) are an exception. These either have better preservation of magnetite, or a different sediment source (i.e., with more magnetite). We suspect that magnetic sulphides (possibly greigite) may 
make a contribution to the magnetization of some of the Permo-Triassic sediments (e.g., blocking temperatures near to $300{ }^{\circ} \mathrm{C}$ in some specimens [Nawrocki 1999]), although positive proof of this is currently lacking. It is clear from low temperature measurements that pyrrhotite is not present (Nawrocki 1999; Hounslow et al. 2008 [this issue]; Hounslow et al. 2008). In some Permian samples goethite appears to make a minor contribution to the natural remanence (Nawrocki 1999).

\section{Problems of remagnetization}

A persistent problem with the Permian and Triassic rocks on Spitsbergen is a partial to occasionally complete remagnetization, evident by an often dominant and steep-down-directed magnetization. This affects the rocks in western Spitsbergen, where the effects of the Palaeocene-Eocene tectonism are most clearly expressed, as well as the flat-lying rocks in central Spitsbergen. Remagnetization is also a problem for the late Mesozoic igneous dykes and sills, common in various parts of Spitsbergen (Krumsiek et al. 1968; Briseid \& Halvorsen 1974; Halvorsen 1972, 1989), which is perhaps indicative of a common origin of these remagnetizations.

Jeleńska (1987) first recognized the secondary nature of the steep magnetizations in Permian limestones. About $50 \%$ of Permian samples studied at the Trygghamna and Kapp Wijk sections (Fig. 1) are totally remagnetized (Nawrocki 1999). In these remagnetized Permian samples only a single distinct component with very steep, positive inclination $\left(75^{\circ}\right.$ to $\left.90^{\circ}\right)$ was isolated. In spite of the extensive tests by Nawrocki (1999), there does not seem to be a distinctly different mineral responsible for the remagnetization, which seems to also reside in magnetite or titanomagnetite, like the primary Permian and Triassic magnetizations.

In the Trygghamna section in western Spitsbergen, some samples from a narrow fault zone also contained a strong remagnetization, but with a negative inclination (Table 2). The NRM intensities of these "fault-zone" samples were about 10 times larger than those partially and fully remagnetized samples outside the fault zone (Nawrocki 1999). A substantial increase in magnetic susceptibility at temperatures of about $200-440{ }^{\circ} \mathrm{C}$ (most often between $420{ }^{\circ} \mathrm{C}$ and $440{ }^{\circ} \mathrm{C}$ ) takes place in most Permian samples containing a primary component (Nawrocki 1999), which is not observed in these totally remagnetized fault-zone samples (Fig. 5). The increase of magnetic susceptibility in the unremagnetized samples is mostly caused by pyrite alteration and oxidation during thermal demagnetization (sediment heating typically produces a variety of strongly magnetic oxides and sulphides [e.g., Noltimier \& Kopacz 1976; Novakova \& Gendler 
1995; Cairanne et al. 2004; Tudryn \& Tucholka 2004]). Some of the lower temperature alteration may be due to clay alteration (e.g., Fig. 5c). Therefore it is possible that alteration due to natural heating (hot fluids in the fault zone?) would produce new magnetic minerals from pyrite, that would acquire a new chemical remanent magnetization (CRM), like that reproduced experimentally by Cairanne et al. (2004).

Anisotropy of magnetic susceptibility (AMS) of the samples containing a primary Permian component displayed conventional bedding-perpendicular minimum susceptibility axes, unlike the AMS axes of the fault-zone remagnetized samples that have strongly scattered directions (Nawrocki 1999). This shows a lack of preferred orientation of the magnetic minerals which contribute to the AMS - as could be expected if these had grown from alteration of cubic pyrite. Hence, it seems probable that both the AMS and the remagnetization (a CRM?) are both related to pyrite alteration through localized heating in the fault zone.

Some 15 to $30 \%$ of specimens from Triassic rocks in central Spitsbergen only contain this secondary overprint magnetization, with the remainder containing evidence of a Triassic magnetization, either by conventional principle component line-fits or great circle trajectories (Hounslow, Hu, Mørk, Vigran et al. 2007; Hounslow et al. 2008a; Hounslow et al. 2008b; Fig. 6). There is evidence for a lithological preference for the remagnetization, with early diagenetic calcite concretions from the Lower Triassic (Deltadalen, Lusitaniadalen and Vendomdalen members) displaying the largest proportion (ca. 40\%) of totally remagnetized specimens (Fig. 6). However, this is not the case for dolomitic and sideritic concretionary lithologies, which display lower rates (ca. 10\%) of total remagnetization than the shale, siltstone and sandstone lithologies (Fig. 6). The reasons for these differences are unclear.

Directional analysis of this secondary magnetization in interpreted Triassic reverse polarity specimens indicates that the secondary magnetization is deflected to the south-west (Table 2, Fig. 7), whereas the overprint directions in the Triassic normal polarity specimens are dominantly in the north-eeast quadrant (Table 2). Since the "reverse" overprint VGP direction means are far from any Phanaerozoic palaeomagnetic poles (Fig. 7), it is probable that this component is composite - a steep-down-directed remagnetization, with the addition of a small amount of Triassic reverse. On the assumption that any secondary magnetization process will have affected both primary reverse and normal polarity samples equally, it seems likely that the overprint directions from Triassic normal polarity specimens may be equally composite in nature (Hounslow et al. 2008b). 
Possible origins of this secondary magnetization are: (a) heating events associated with the intrusion of the late Mesozoic dykes and sills of the High Arctic Large Igneous Province (HALIP) defined by Maher (2001); (b) heating and fluid migration associated with PalaeoceneEocene transpression in western Spitsbergen: (c) a Brunhes-age viscous magnetization; and (d) Brunhes-age weathering events (e.g., permafrost formation and thawing? [Løvlie \& Putkonen 1996]).

The mean VGP directions of the overprints fall far from the cluster of poles associated with the primary directions of HALIP intrusions (Fig. 7), suggesting that it is unlikely these intrusions have induced a large-scale remagnetization of Permian and Triassic rocks. Naturally, it is possible that this process may have occurred close to these intrusions.

The organic matter maturation in the Triassic clearly shows elevated values of maximum heating in western Spitsbergen compared to central and eastern Svalbard (Bjorøy et al. 1978; Bjorøy et al. 2007). It seems probable this enhanced organic matter maturation may be associated with deeper maximum burial (higher maximum temperature) in western Spitsbergen, rather than widespread fluid migration in the low permeability mudrocks of the Triassic. In addition, the Triassic rocks from central Spitsbergen show no evidence that the coarser-grained lithologies (sandstone and siltstones) are any more remagnetized than the shales (Fig. 6), which would suggest that wide-scale fluid migration as a process of remagnetization is not viable.

However, local hot fluid migration is a viable mechanism in western Spitsbergen, as shown by the above example of remagnetization from a fault zone in the Permian (Fig. 5). Nevertheless, considering that the Palaeocene-Eocene has a complex pattern of polarity changes, fluid flow or orogenic-related heating seems unable to fully account for widespread normal polarity remagnetizations. The mean pole positions of the Triassic "normal" overprints do not fall directly over the Palaeocene-Eocene (65 to $31 \mathrm{Mya}$ ) part of the APWP for Laurussia, but somewhat to the west (Fig. 7). Only one of these poles shows significant overlap with the APWP (pole 10 in Table 2), although, considering the uncertainties in the APWP (in part expressed by the two APWP solutions in Fig. 7), some of these overprints could be considered as possible Palaeocene-Eocene remagnetization. The Permian example above also demonstrates that these remagnetizations in western Spitsbergen are acquired after Palaeocene-Eocene folding. Also, Vincenz et al. (1981) implicated Tertiary-age remagnetization for both reverse and normal polarity magnetizations in their study of HALIP igneous rocks. 
Brunhes-age viscous remagnetization has been evaluated as a viable mechanism in HALIP igneous rocks in western Spitsbergen (Sandel \& Halvorsen 1973). Preliminary studies of viscous magnetization acquisition on the Triassic rocks also demonstrate that these rocks have the ability to acquire substantial viscous components (Fig. 8). This demonstrates that at least part of the remagnetization problem is associated with a Brunhes-age viscous magnetization, even in the dolomitic lithologies in the Lower Triassic, which have somewhat more stable palaeomagnetic behaviour than other rock types (Figs. 6, 8).

In conclusion, the remagnetization which is persistent in the Permian and Triassic rocks of Spitsbergen has several characteristics. (1) It is mostly younger than the Palaeocene-Eocene folding, although its direction is not easy to fully resolve, due to demagnetization stability overlap with older magnetizations. (2) Triassic sediments in central Spitsbergen show some lithological discrimination of remagnetization prevalence, which is not understood at this time.

(3) Bruhnes-age viscous magnetizations are in part responsible for the remagnetization in central Spitsbergen. (4) Localized fluid migration along fault zones is a viable mechanism for remagnetization in western Spitsbergen. (5) Palaeocene-Eocene orogensis and heating may have made a contribution to remagnetization in western Spitsbergen.

\section{Magnetostratigraphy}

\section{The Permian polarity timescale}

A dominantly reverse polarity interval extends from the mid Carboniferous to around the mid Permian - the Permo-Carboniferous Reverse Superchron (PCRS), succeeded by an interval of normal and reverse polarity in the late Permian. However, the precise location of the top of the PCRS relative to the modern Permian stages is controversial (Gradstein et al. 2004; Menning et al. 2006; Steiner 2006). This controversy in part relates to how best to correlate the older Permian regional subdivisions to the modern stage subdivisions (Gialanella et al. 1997; Menning et al. 2006). It is also probable that relatively brief intervals of normal polarity occurred in the early parts of the mid Permian, as the PCRS was ending, during the Wordian and Capitanian (Steiner 2006), so that there was probably not a "sudden end" to the PCRS. A robust solution to the magnetostratigraphic timescale is hampered by the poor consistency of mid to late Permian magnetostratigraphic data from marine rocks with good biostratigraphic age control (Gallet et al. 2000; Steiner 2006). In contrast, data from poorly dated Russian platform red beds unequivocally 
locate the top of the PCRS in the Tatarian (Pechersky \& Khramov 1973; Gialanella et al. 1997). In the newest interpretations, the top of the PCRS is suggested to be near the base of the Capitanian (Gradstein et al. 2004; Menning et al. 2006), regarded as contemporaneous with the lower part of the normal magnetozones in the Russian Tatarian (Menning et al. 2006; Fig. 9). Differences relate to the youngest age assigned to the Tatarian. An alternative analysis by Steiner (2006) suggests evidence for repeatable brief normal polarity magnetozones in the Wordian, which she suggests to be the top of the PCRS (Fig. 9).

\section{Studies of the Permian on Spitsbergen}

The palaeomagnetic studies of Jeleńska \& Vincenz (1985) and Jeleńska (1987) covered the late Carboniferous Hymefjellet Fm., the latest Carboniferous-Lower Permian Treskelodden Fm. and the mid Permian part of the Kapp Starostin Fm. and detected only normal polarity. Their results are clearly questionable, since they sampled intervals which correspond mostly to the PCRS, sampled predominantly in western Spitsbergen and used mostly alternating field demagnetization. They probably failed to fully separate the normal overprint magnetization from the Permian magnetization, so their extracted directions are probably composite, consisting of a normal overprint plus Permian reverse.

Modern magnetostratigraphic studies of the Permian on Spitsbergen have been undertaken by Nawrocki \& Grabowski (2000) in order to try to recognize the upper boundary of the PCRS and to try and establish the position of the first major overlying normal polarity interval, in the mid to late Permian. Rocks from the Gipsdalen and Tempelfjorden groups were sampled by Nawrocki \& Grabowski (2000) for magnetostratigraphy at Kapp Schoultz (Tempelfjorden, Fig. 1), Kapp Wijk (western Dicksonland, Fig. 1) and Trygghamna (western Spitsbergen). Nawrocki \& Grabowski (2000) collected some 300 specimens and in spite of numerous gaps in the magnetic polarity data for the sections (caused by complete remagnetization), these data do support a fragmentary magnetostratigraphy (Fig. 9). These samples are dominantly reverse polarity, but are interrupted by three limited thickness normal polarity intervals, one within the base of the Tyrrellfjellet Member (Mb.), one in the lower parts of the Svenskegga Mb. and a probable third in the base of the Hovtinden Mb. (Fig. 9). As discussed previously only $12 \%$ of specimens possessed data suitable for robust conventional principle-component line-fits (Nawrocki 1999), but with some $38 \%$ of additional specimens displaying great circle trends, which could reliably be used to interpret the polarity. Nawrocki \& Grabowski (2000) used a specimen data-quality classification, which we have utilized in displaying a composite magnetostratigraphy from each section (Fig. 9). 
Reverse polarity in the Tyrellfjellet $\mathrm{Mb}$. was interrupted by a normal magnetozone just below the level of Palaeoaplysina buildups in the upper part of the Brucebyen Beds (data of Nawrocki \& Grabowski 2000, mapped onto the modern lithostratigraphy). This magnetozone comprised two adjacent specimens (characteristic remanence directions in stratigraphic coordinates, $\mathrm{D} / \mathrm{I}=348^{\circ}$ $145^{\circ} ; 355^{\circ} / 48^{\circ}$ ) some $40 \mathrm{~m}$ above its base (Fig. 9). In sections in the Urals and Central Asia, in the top-part of the Gzhelian (latest Carboniferous) there is a consistently detected normal magnetozone (Khramov \& Davydov 1984; Davydov \& Khramov 1991; Davydov \& Leven 2003). In sections in Asia, a second normal magnetozone occurs in the basal Asselian (Khramov \& Davydov 1993; Davydov \& Leven 2003). Nilsson \& Davydov (1997) have placed the Gzhelian-Asselian boundary within the top of the Brucebyen Beds and its transition into the overlying beds. This suggests that the tentative normal magnetozone in the Tyrellfjellet Mb. probably represents the equivalent of the late Gzhelian magnetozone identified by Khramov \& Davydov (1993). Whilst the normal polarity interval in the Brucebyen Beds is only defined by two specimens, and is therefore somewhat tentative, this magnetozone does demonstrate potential in defining the Carboniferous-Permian boundary in other sections on Spitsbergen.

Normal polarity was interpreted in three specimens in the lower part of the Svenskegga Mb., two at Kapp Wijk (30 m from the base of the Kapp Starostin Fm; Fig. 9) and one at Trygghamna, which probably represent the equivalent normal magnetozone (Nawrocki \& Grabowski 2000). This, like the lower normal magnetozone, was regarded as tentative because it was based on poorer quality data in which polarity was determined using directional trends during demagnetization. However, this normal magnetozone compares favorably with the "Word-N" magnetozone (Fig. 9) of Steiner (2006), identified in successions in North America and Transcaucasia.

The first fully reliable normal magnetozone appears in cherts from the base of the Hovtinden Mb. at Trygghamna (220 m above the base of the Kapp Starostin Fm.). This was based on three sample levels at $275 \mathrm{~m}, 278 \mathrm{~m}$ and $283 \mathrm{~m}$ in the section, with 3 out of 4 specimens displaying linear-trajectory line-fits (Nawrocki \& Grabowski 2000). These specimens yield a mean direction in stratigraphic coordinates of $008^{\circ} / 34^{\circ}(\mathrm{N}=4, \mathrm{k}=16$; Fig. 9). There is no confirmation of this magnetozone from the Kapp Wijk section (Fig. 9). This normal magnetozone probably represents one or other of the normal magnetozones in the Capitanian timescale of Steiner (2006). Reverse polarity seems to dominate the topmost part of the Kapp Starostin Fm. (Figs. 9, 10), which would suggest most of the Upper Permian (Lopingian) may be missing on 
Spitsbergen, consistent with some biostratigraphic interpretations (Nakazawa et al. 1990; Nakrem et al. 1992). Alternatively, it may be that the uppermost Kapp Starostin Fm. is earliest Lopingian in age, which is dominated by reverse polarity (Fig. 9) in the magnetostratigraphic timescale of Steiner (2006).

Some have suggested the Kapp Starostin-Vardebukta Fm. boundary may be entirely conformable in western Spitsbergen (Wignall et al. 1997), which is at odds with both the biostratigraphy and magnetostratigraphy (Fig. 9). However, substantial parts of the Kapp Starostin Fm. have not allowed recovery of suitable magnetostratigraphic data to assess if substantive normal polarity magnetozones are present. Hence a target for future studies of the Permian on Spitsbergen must be to find suitable sections in the Kapp Starostin Fm., perhaps in central Spitsbergen, that are not so extensively affected by the Cenozoic overprint.

\section{Triassic magnetostratigraphy}

The sediments of the Sassendalen Group began to be deposited during the latest Changhsingian (latest Permian). This is evident by the latest Permian palynofloral extinction event in central Spitsbergen (Mørk, Elvebakk et al. 1999) and by the associated organic carbon negative isotopic excursion (prior to the Permian-Triassic boundary; Yin et al. 2001), which occurs some $7 \mathrm{~m}$ above the base of the Vardebukta Fm in western Spitsbergen in the Festningen section (Wignall et al. 1997).

Palaeomagnetic data from the Triassic of Spitsbergen (Hounslow, Hu, Mørk, Vigran et al. 2007; Hounslow et al. 2008a; Hounslow et al. 2008b), shows a greater proportion of specimens with linear-trajectory, principle component line-fits than the Permian data (25\% at Milne Edwardsfjellet, $36 \%$ at Vikinghøgda, $60 \%$ at Dalsnuten). This apparent difference from the Permian data of Nawrocki \& Grabowski (2000) probably relates in part to differing demagnetization schemes, and magnetometers, as much as differing intrinsic magnetic properties. The similarity to the Permian data is that most (except for the Upper Triassic at Dalsnuten) of the specimen polarity interpretations are based on great circle trends during demagnetization (Hounslow et al. 2008a; Hounslow et al. 2008b).

The magnetostratigraphy of the Spitsbergen Lower Triassic shows a reasonable degree of correspondence between the studies of Nawrocki \& Grabowski (2000) and Hounslow et al. (in press). The correlations among the Trygghamna and Tschermakfjellet sections with wide sample spacing and that at Vikinghøgda, with closer sample spacing, are, however, largely controlled by 
the lithostratigraphy (Hounslow et al. 2008a; Fig. 10). The correlations between the Milne Edwardsfjellet and Vikinghøgda sections are additionally constrained with biostratigraphy (Hounslow et al. 2008a).

The basal normal polarity which characterizes the lower part of the Griesbachian (Ogg \& Steiner 1991; Gallet et al. 2000; Steiner 2006) is only clearly shown in the successions at Vikinghøgda (Fig. 10), whereas this interval was not apparently detected in sections studied by Nawrocki \& Grabowski (2000) at Trygghamna and Tschermakfjellet. The magnetostratigraphy demonstrates the base of the Olenekian (defined by first occurrence of the conodont Neospathodus waageni, Krystyn et al. 2007) probably occurs within the base-part of the Lusitaniadalen Mb. (Hounslow et al. 2008b). The top of the Selmaneset Mb. in western Spitsbergen may equate to a level near the top of the Deltadalen Mb. in central Spitsbergen (Fig. 10), since the Promyalina-bearing sandstone (the Brevassfjellet Bed) contains conodonts probably indicative of an interval in the early-mid-Dienerian (Nakrem et al. 2008 [this issue]). The overlying Siksaken Mb. contains conodonts indicating a later Dienerian age (Nakrem et al. 2008). These data along with the lithostratigraphic correlation (Fig. 10) suggest that the Vardebukta Fm. of western Spitsbergen extends into the Olenekian (i.e., equivalent of Vh6r magnetozone, Fig. 10), rather than terminating near the Induan-Olenekian boundary.

The upper reverse polarity magnetozone in the Vendomdalen $\mathrm{Mb}$. from Milne Edwardsfjellet (i.e., MF2r; Hounslow et al. 2008a) appears to be the equivalent of the Tf5r magnetozone from Tschermakfjellet (Fig. 10). This reverse magnetozone appears to be absent at Vikinghøgda, due to probable erosion prior to deposition of the Botneheia Fm. and the absence of the lowest part of the Botneheia Fm. at Vikinghøgda (Hounslow et al. 2008b). The immediately underlying reverse magnetozone in the Vendomdalen Mb. (i.e., Tf4r, Vh8n.2r and MF2n.2r; Fig. 10), whilst in all three sections represented by a single sampling level, is confirmed in all three sections (Fig. 10).

The challenges remaining in the Lower Triassic are extraction of a more detailed magnetostratigraphy from western Spitsbergen to better understand the relationship between the lithostratigraphic boundaries in western Spitsbergen and those now defined in central Spitsbergen by Mørk, Dallmann et al. (1999). In combination with the magnetostratigraphic data from the Sverdrup Basin of Ogg \& Steiner (1991), Spitsbergen is likely to be the key area in the world for defining the Lower Triassic magnetic polarity timescale (Hounslow et al. 2008b). 
The bio-magnetostratigraphy of the Middle and Upper Triassic has been detailed by Hounslow, Hu, Mørk, Weitschat et al. (2007) and Hounslow et al. (2008a) from Vendomdalen in central Spitsbergen, supported by ammonoid, palynology and conodont data. The work on the Middle Triassic shows a close similarity to published works on the Tethyan Middle Triassic, suggesting, as hinted at by the ammonoids (Weitschat \& Dagys 1989; Hounslow, Hu, Mørk, Vigran et al. 2007), that the upper part of the Ladinian is missing (Fig. 11). The key point of the Middle Triassic work from Spitsbergen is that this validates the pattern of polarity changes through the Anisian, suggested by other workers from lower palaeolatitudes (Nawrocki \& Szulc 2000; Muttoni et al. 2000), adding detail particularly in the lower part of the Anisian. It also demonstrates the much reduced sedimentation rate in central Spitsbergen during the late Anisian and its transition into the early Ladinian.

There is currently only a rudimentary knowledge of the Upper Triassic magnetostratigraphy on Spitsbergen, which is only well defined in the Tschermakfjellet Fm. and lower part of the De Geerdalen Fm. in the Vendomdalen area, through what appears to be mostly the Carnian (Hounslow, Hu, Mørk, Weitschat et al. 2007). In terms of palaeomagnetic behaviour, the Upper Triassic probably provides the best-type of palaeomagnetic properties in the whole of the Spitsbergen Permian-Triassic, since only about $15 \%$ of samples are dominated by the Cenozoic overprint (Fig. 6). The upper Carnian to latest Triassic has been intensely studied for magnetostratigraphy in other areas of the world, so understanding of the polarity pattern during this interval is good. This is advantageous for further magnetostratigraphic studies in Svalbard since this interval is the most poorly characterized in terms of age control in the whole of the Permian-Triassic of the archipelago.

\section{Conclusions}

1) The Permian to Triassic palaeomagnetic data generally confirms the Baltica/European credentials of the Spitsbergen apparent polar wander path.

2) The persistent overprint magnetization, which in part plagues palaeomagnetic studies of the Permian and Triassic, is a post-folding remagnetization. Its age may vary from Tertiary to Holocene. Its origin is likely to be not of one single origin, but may be viscous or weathering-related, or locally in western Spitsbergen it may be of fluid-flow origin. The often strong overlap of this remagnetization component with the primary Permian and Triassic magnetizations is the primary reason that only small to moderate proportions of specimens are characterized by classic linear trajectory line-fits to demagnetization data. 
3) A tentative normal magnetozone in the base of the Tyrrellfjellet Mb. (Gipsdalen Group) provides a good marker for the close proximity of the Carboniferous-Permian boundary. Together with a second normal magnetozone in the lowermost Permian, known from other areas at this level, this may help constrain correlations at this level in future studies.

4) Two normal magnetozones, one in the base of the Svenskegga Mb. (Kapp Starostin Fm.), and a second in the lower part of the Hovtinden Mb. (Kapp Starostin Fm.) are probable equivalents to Wordian and Capitanian-age magnetozone identified by Steiner (2006) from other sections of this age. The younger of these magnetozones is strongly supported by multiple specimens on multiple horizons, not substantially affected by remagnetization. The upper parts of the Kapp Starostin Fm. are a key target for future magnetostratigraphic work on Spitsbergen to refine the mid to late Permian chronostratigraphy on Svalbard.

5) The bio-magnetostratigraphy through the Lower Triassic on Spitsbergen probably provides the key area in the world for the robust construction of the magnetic polarity timescale over this interval.

6) Newer timescales for the Triassic have some $28 \mathrm{My}$ of the $51 \mathrm{My}$ of Triassic time now occupied by the Upper Triassic. This fact makes it crucially important to better understand the detailed sequence and chronostratigraphy of the Svalbard Upper Triassic. This can be supported by the detailed data available from magnetostratigraphic studies.

\section{Acknowledgements}

Atle Mørk provided some useful discussion on the Lower Triassic in western Spitsbergen. Simon Chew helped draft figures. The presented Triassic sample data was measured by Mengyu $\mathrm{Hu}$, Clare Peters and Vassil Karloukovski. Three anonymous reviewers provided many constructive comments.

\section{References}

Bergh S. G. \& Grogan P. 2003. Tertiary structure of the Sørkapp-Hornsund region, south Spitsbergen, and implications for the offshore southern extension of the fold-thrust belt. Norwegian Journal of Geology 83, 43-60.

Besse J. \& Courtillot V. 2002. Apparent and true polar wander and the geometry of the geomagnetic field over the last 200 Myr. Journal of Geophysical Research—Solid Earth 107(B11), doi:10.1029/2000JB000050. 
Bjorøy M., Hall P.B. \& Mørk A. 2006. Triassic hydrocarbon source rocks on Svalbard and in the Barents Sea. Boreal Triassic 2006, NGF Abstracts and Proceedings of the Geological Society of Norway 3, 42-55.

Bjorøy M., Vigran J.O. \& Rønningsland T.M. 1978. Source rock evaluation of Mesozoic shales from Svalbard. IKU Open Report 160/1/78. Trondheim: Continental Shelf Institute.

Braathen A., Andresen A., Hansen A.-I., Bergvik A., Bergh S., Karlsen F. \& Maher Jr. H. 1999. Kinematics of the Isfjorden-Ymerbukta Fault Zone: a dextral oblique-thrust ramp in the Tertiary fold-thrust belt of Spitsbergen. Norsk Geologisk Tidsskrift 79, 227-239.

Briseid E. \& Halvorsen E. 1974. The primary magnetic remanence of a dolerite sill from northeast Spitsbergen. Physics of the Earth and Planetary Interiors 9, 45-50.

Broglio Loriga C., Gianolla P., Franco Laghi G., Lowrie W., Manfrin S., Mastandrea A., Mietto P., Muttoni G., Neri C., Posenato R., Rechichi M. Rettori R., Roghi G., Cirilli S., De Zanche V. \& Di Bari, D. 1999. The Prati di Stuores/Stuores Wiesen section (Dolomites, Italy): a candidate Global Stratotype Section and Point for the base of the Carnian Stage. Rivista Italiana di Paleontologia e Stratigrafia 105, 37-78.

Cairanne G., Aubourg C., Pozzi J.-P., Moreau M.-G., Decamps T. \& Marolleau G. 2004. Laboratory chemical remanent magnetization in a natural claystone: a record of two magnetic polarities. Geophysical Journal International 159, 909-916

Dallmann W.K. (ed.) 1999. Lithostratigraphic lexicon of Svalbard. Tromsø: Norwegian Polar Institute.

Davydov V.I. \& Khramov A.N. 1991. Palaeomagnetism of Upper Carboniferous and Lower Permian in the Karachatyr region (southern Ferhgana) and the problems of correlation of the Kiaman hyperzone [Paleomagnetizm verhnego karbona i nizhnej permi Kara'atyra (Ju. Fergana) i problemy korreljacii razrezov giperzony Kiama.]. In A.N. Khramov (ed.): Paleomagnetizm i paleogeodinamika territorii SSSR. (Palaeomagnetism and palaeogeodynamics of the territory of USSR.) Pp. 45-53.

Transactions of VNIGRI. Leningrad: VNIGRI .

Davydov V.I. \& Leven A.N. 2003. Correlation of Upper Carboniferous (Pennsylvanian) and Lower Permian (Cisuralian) marine deposits of the Peri-Tethys. Palaeogeography Palaeoclimtology Palaeoecology 196, 39-57. 
Doré A.G. 1991. The structural foundation and evolution of Mesozoic seaways between Europe and the Arctic Sea. Palaeogeography Palaeoclimatology Palaeoecology 87, 441-492.

Egorov A.Y. \& Mørk A. 2000. The east Siberian and Svalbard Triassic successions and their sequence stratigraphical relationships. In G.H. Bachmann \& I. Lerche (eds.): Epicontinental Triassic. Vol. III. Zentralblatt für Geologie und Paläontologie Teil 1. Pp. 1377-1430. Stuttgart: E. Schweizerbart'sche Verlagsbuchhandlung.

Gallet Y., Besse J., Krystyn L. \& Marcoux J. 1992. Magnetostratigraphy of the late Triassic Boucektasi Tepe section (south western Turkey): implications for changes in magnetic reversal frequency. Physics of the Earth Planetary Interior 93, 273-282.

Gallet Y., Besse J., Krystyn L., Theveniant H. \& Marcoux J. 1994. Magnetostratigraphy of the Mayerling section (Austria) and Erebkolu Merzarlik (Turkey) section: improvement of the Carnian (late Triassic) magnetic polarity time scale. Earth Planetary Science Letters 125, 173-191.

Gallet Y., Krystyn L., Besse J., Saidi A. \& Ricou L-E. 2000. New constraints on the Upper Permian and Lower Triassic geomagnetic polarity timescale from the Abadeh section (central Iran). Journal of Geophysical Research 105-Solid Earth 105(B2), 2805-2815.

Gialanella P.R., Heller F., Haag M., Nurgaliev D., Borisov A., Burov B., Jasonov P., Khasanov D., Ibragimov S. \& Zharkov I. 1997. Late Permian magnetostratigraphy on the Eastern Russian Platform. Geologie en Mijnbouw. 76, 145-154.

Gradstein F., Ogg J. \& Smith A. 2004. A geologic time scale 2004. Cambridge: Cambridge University Press.

Halvorsen E. 1972. A palaeomagnetic study of two volcanic formations from northern Spitsbergen. Norsk Polarinstitutt Årbok 1970, 70-75.

Halvorsen E. 1989. A palaeomagnetic pole position of Late Jurassic/Early Cretaceous dolerites from Hinlopenstretet, Svalbard, and its tectonic implications. Earth Planetary Science Letters 94, 398-408.

Hounslow M.W., Hu M., Mørk A., Vigran J.O., Weitschat W. \& Orchard M.J. 2007a. Magneto-biostratigraphy of the lower part of the Kapp Toscana Group (Carnian), Vendomdalen, central Spitsbergen, Arctic Norway. Journal of the Geological Society London 164, 581-597. 
Hounslow M.W., Hu M., Mørk A., Weitschat W., Vigran J.O., Karloukovski V. \&. Orchard. M.J. 2007: Intercalibration of Boreal and Tethyan timescales: the magnetobiostratigraphy of the Middle Triassic and the latest Early Triassic, central Spitsbergen (Arctic Norway). In S.G. Lucas \& J.A. Spielmann (eds.): The global Triassic. New Mexico Museum of Natural History and Science Bulletin 41, 68-70.

Hounslow M.W., Hu M., Mørk A., Weitschat W., Vigran J.O., Karloukovski V. \&. Orchard. M.J. 2008a (this issue). Intercalibration of Boreal and Tethyan timescales: the magneto-biostratigraphy of the Middle Triassic and the latest Early Triassic, central Spitsbergen (Arctic Norway). Polar Research 27, xxx-xxx.

Hounslow M.W., Mørk A., Peters C. \& Weitschat W. 1996. Boreal Lower Triassic magnetostratigraphy from Deltadalen, central Svalbard. Albertiana 17, 3-10.

Hounslow M.W., Peters C., Mørk A., Weitschat W. \& Vigran J.O. 2008b. Magnetobiostratigraphy of the Vikinghøgda Formation, Svalbard (Arctic Norway) and the geomagnetic polarity timescale for the Lower Triassic. Geological Society of America Bulletin. 120, 1305-1325.

Khramov A.N. \& Davydov V.I. 1984. Palaeomagnetism of some Upper Carboniferous and Lower Permian layers in the south of the U.S.S.R. and the problems of the structure of the Kiaman hyperzone. In A.N. Khramov (ed.) Paleomagnetic methods in stratigraphy [Paleomagnitnye metody v stratigrafii]. Pp. 55-73. St. Petersburg: Trudy VNIGRI. [Paleomagnetizm nekotoryh verhnekamennougol'nyh i nizhnepermskih tolšč juga SSSR i problema struktury giperzony Kiama].

Jeleńska M. 1987. Aspects of pre-Tertiary palaeomagnetism of Spitsbergen and their tectonic implications. Tectonophysics 139, 99-106.

Jeleńska M. \& Lewandowski M. 1986. A palaeomagnetic study of Devonian sandstone from central Spitsbergen. Geophysics Journal of the Royal Astronomical Society 87, 617-632.

Jeleńska M. \& Vincenz S.A. 1985.Origin of the magnetization of Permo-Carboniferous sediments of Spitsbergen, Svalbard Archipelago. Earth Planetary Science Letters 85, 173-182.

Kent D.V. \& Tauxe L. 2005. Corrected late Triassic latitudes for continents adjacent to the North Atlantic. Science 307, 240-244. 
Khramov A.N. \& Davydov V.I. 1993. Results of palaeomagnetic investigations. Permian system: guides to geological excursions in the Uralian type localities. Occasional Publication ESRI, New Series, 10, 34-42. Earth Sciences and Resources Institute, University of South Carolina.

Krajewski K.P. 2000. Phosphorus concentration and organic carbon preservation in the Blanknuten Member (Botneheia Formation, Middle Triassic), Sassenfjorden, Spitsbergen. Studia Geologica Polonica 116, 139-173.

Krumsiek K., Nagel J. \& Nairn A.E.M. 1968. Record of palaeomagnetic measurements on some igneous rocks from the Isfjorden region, Spitsbergen. Norsk Polarinstitutt Årbok 1966, 76-83.

Krystyn L., Bhargava O.N. \& Richoz S. 2007. A candidate GSSP for the base of the Olenekian Stage: Mud at Pin Valley; district Lahul \& Spiti, Hamachal Pradesh (western Himalaya), India. Albertiana 35, 5-29.

Løvlie R. \& Putkonen J. 1996. Dating of thaw depths in permafrost terrain by the palaeomagnetic method: experimental acquisition of a freezing remanent magnetization. Geophysical Journal International 125, 850-856.

Maher H.D. Jr. 2001. Manifestations of the Cretacous High Arctic large igneous province in Svalbard. Journal of Geology 109, 91-104.

McFadden P.L. \& McElhinny M.W. 1990. Classification of the reversal test in paleomagnetism: Geophysical Journal International 103, 725-729.

Menning M., Davydov V.I., Devuyst F.-X., Forke H.C., Grunt T.A., Hance L., Heckel P.H., Izokh N.G., Jin Y.-G., Jones P.J., Kotlyar G.V., Kozur H.W., Nemyrovska T.I., Schneider J.W., Wang X.-D., Weddige K., Weyer D., Work D.M., Alekseev A.S. \& Chuvashov B.I. 2006. Global time scale and regional stratigraphic reference scales of central and west Europe, east Europe, Tethys, south China, and North America as used in the Devonian-Carboniferous-Permian Correlation Chart 2003 (DCP 2003). Palaeogeography Palaeoclimatology Palaeoecology 240, 318-372.

Michalski K. \& Lewandowski, M. 2004. Palaeomagnetic results from the Middle Carboniferous rocks of the Hornsund region, southern Spitsbergen: preliminary report. Polish Polar Research 25, 169-182. 
Mørk A., Dallmann W.K., Dypvik H., Johannessen E.P., Larssen G.B., Nagy J., Nøttvedt A., Olaussen S., Pchelina T.M. \& Worsley D. 1999: Mesozoic lithostratigraphy. In W.K. Dallmann (ed.): Lithostratigraphic lexicon of Svalbard. Pp. 127-214. Tromsø: Norwegian Polar Institute.

Mørk A., Elvebakk G., Forsberg A.W, Hounslow M.W., Nakrem H.A., Vigran J.O. \& Weitschat W. 1999. The type section of the Vikinghøgda Formation: a new Lower Triassic unit in central and eastern Svalbard. Polar Research 18, 51-82.

Mørk A., Vigran J.O., Korchinskaya M.V., Pchelina T.M., Fefilova L.A., Vavilov M.N. \& Weitschat W. 1992: Triassic rocks in Svalbard, the Arctic Soviet islands and the Barents Shelf: bearing on their correlations. In T.O. Vorren et al. (eds.): Arctic geology and petroleum potential: proceedings of the Norwegian Petroleum Society Conference, 1517 August 1990, Tromsø, Norway. Pp. 457-479. Amsterdam: Elsevier.

Muttoni G., Gaetani M., Budurov K., Zagorchev I., Trifonova E., Ivanova D., Petrunova L. \& Lowrie W. 2000. Middle Triassic palaeomagnetic data from northern Bulgaria: constraints on Tethyan magnetostratigraphy and palaeogeography. Palaeogeography Palaeoclimatology Palaeoecology 160, 223-237.

Nakazawa K., Suzuki H., Kumon F. \& Winsnes T. S. 1990: Scientific results of the Japanese Geological Expedition to Svalbard 1986. In T. Tatsumi (ed.): The Japanese Scientific Expedition to Svalbard 1983-1988. Pp. 179-214. Tokyo: Kyoikusha Press.

Nakrem H.A., Nilsson I. \& Mangerud G. 1992. Permian biostratigraphy of Svalbard (Arctic Norway) — a review. International Geological Review 34, 933-959.

Nakrem H.A., \& Orchard, M.J., Weitschat W., Hounslow M.W., Beatty T. \& Mork A. 2008 (this issue). Triassic conodonts from Svalbard and their Boreal correlations-a review. Polar Research 27, xxx-xxx.

Nawrocki J. 1999. Palaeomagnetism of Permian through Early Triassic sequences in central Spitsbergen: implications for palaeogeography. Earth and Planetary Science Letters 169, 59-70.

Nawrocki J. \& Grabowski J. 2000. Palaeomagnetism of Permian through Early Triassic sequences in central Spitsbergen: contribution to magnetostratigraphy. Geological Quarterly 44, 109-117.

Nawrocki J. \& Szulc J. 2000. The Middle Triassic magnetostratigraphy from the PeriTethys basin in Poland. Earth Planetary Science Letters 182, 77-92. 
Nilsson I. \& Davydov V.I. 1997. Fusulinid biostratigraphy in the Upper Carboniferous (Gzelian) and Lower Permian (Asseslian-Sakmarian) successions of Spitsbergen, Arctic Norway. Permophiles 30, 18-24.

Noltimier H. \& Kopacz M. 1976. Thermomagnetic study of coal and associated roof shale. IEEE Transactions on Magnetics 12, 528 - 531.

Novakova A. A. \& Gendler T. S. 1995. Metastable structural-magnetic transformations in sulphides in the course of oxidation. Journal of Radioanalytical and Nuclear Chemistry 190, 363-368.

Ogg J.G. \& Steiner M.B. 1991. Early Triassic polarity time-scale: integration of magnetostratigraphy, ammonite zontationzonation and sequence stratigraphy from stratotype sections (Canadian Arctic Archipelago). Earth and Planetary Science Letters 107, 69-89.

Pechersky D.M. \& Khramov A.N. 1973. Mesozoic palaeomagnetic scale of the USSR. Nature 244, 499-501.

Rowley D.B. \& Lottes A.L. 1988. Plate-kinematic reconstructions of the North Atlantic and Arctic: late Jurassic to present. Tectonophysics 155, 73-120.

Samuelsberg T.J. \& Pickard N.A.H. 1999. Upper Carboniferous to Lower Permian transgressive regressive sequences of central Spitsbergen, Arctic Norway. Geological Journal 34, 393-411.

Sandal S.T \& Halvorsen E. 1973. Late Mesozoic palaeomagnetism from Spitsbergen: implications for continental drift in the arctic. Physics of the Earth and Planetary Interiors 7, 125-132.

Steiner M. B. 2006. The magnetic polarity timescale across the Permian-Triassic boundary. In S.G. Lucas et al. (eds.): Non-marine Permian biostratigraphy and biochronology. Pp. 15-38. London: Geological Society of London..

Stemmerik L. 2000. Late Palaeozoic evolution of the North Atlantic margin of Pangaea. Palaeogeography Palaeoclimatology Palaeoecology 161, 95-126.

Stemmerik L. \& Worsley D. 2005. 30 years on-Arctic Upper Palaeozoic stratigraphy, depositional evolution and hydrocarbon prospectivity. Norwegian Journal of Geology 85, 151-168.

Tauxe L. 2005. Inclination flattening and the geocentric axial dipole hypothesis. Earth and Planetary Science Letters 233, 247-261 
Tauxe L. \& Kent D.V. 2004. A simplified statistical model for the geomagnetic field and the detection of shallow bias in palaeomagnetic inclinations: was the ancient magnetic field dipolar? In J.E.T. Channell et al. (eds.): Timescales of the palaeomagnetic field- Pp. 101-116. Washington, D.C.: American Geophysical Union.

Torsvik T.H. \& Cocks L.R.M. 2005. Norway in space and time: a centennial cavalcade. Norwegian Journal of Geology 85, 73-86.

Torsvik T.H., Løvlie R. \& Sturt B.A. 1985. Palaeomagnetic argument for stationary Spitsbergen relative to the British Isles (western Europe) since the late Devonian and its bearing on North Atlantic reconstruction. Earth Planetary Science Letters 75, 278-288.

Tudryn A. \& Tucholka P. 2004. Magnetic monitoring of thermal alteration for natural pyrite and greigite. Acta Geophysica Polonica. 52, 509-520.

Van der Voo R. \& Torsvik T.H. 2001. Evidence for late Palaeozoic and Mesozoic nondipole fields provides an explanation for the Pangaea reconstruction problems. Earth and Planetary Science Letters 187, 71-81.

Van der Voo R. \& Torsvik T.H. 2004: The quality of the European Permo-Triassic palaeopoles and its impact on Pangaea reconstructions. In J.E.T. Channell et al. (eds.): Timescales of the palaeomagnetic field. Pp. 29-42. Washington, D.C.: American Geophysical Union.

Vincenz S.A. \& Jeleńska M. 1985. Palaeomagnetic investigations of Mesozoic and Palaeozoic rocks from Svalbard. Tectonophysics 114, 163-180.

Vincenz S.A., Cossak D., Duda S.J., Birkenmajer K., Jeleńska M., Kadzialko-Hofmok1 M., Kruczyk J. 1981. Palaeomagnetism of some late Mesozoic dolerite dykes of south Spitsbergen. Geophysics Journal of the Royal Astronomical Society 67, 599-614.

Vincenz S.A., Jeleńska M., Auehsazian K \& Birkenmajer K. 1984. Palaeomagnetism of some late Mesozic dolerite sill of eastern central Spitsbergen; palaeomagnetic implications. Geophysics Journal of the Royal Astronomical Society 78, 751-773.

Watts D.R. 1985. Palaeomagnetism of the Lower Carboniferous Billefjorden Group, Spitsbergen. Geological Magazine 122, 383-388.

Weitschat W. \& Dagys A.S. 1989. Triassic biostratigraphy of Svalbard and a comparison with NE-Siberia. Mitteilungen Geologisch-Paläontologisches Institut Universität Hamburg 68, 179-213. 
Wignall P.B., Morante R. \& Newton R. 1997. The Permo-Triassic transition in Spitsbergen: $\delta^{13} \mathrm{C}_{\text {org }}$ chemostratigraphy, Fe and $\mathrm{S}$ geochemistry, facies, fauna and trace fossils. Geological Magazine 135, 47-62.

Yin H., Zhang K., Tong J., Yang Z. \& Wu S. 2001. The Global Stratotype Section and Point (GSSP) of the Permian-Triassic boundary. Episodes 24, 102-114.

\section{Figure Captions}

Fig. 1. Location map and simplified geology map of central and southern Svalbard (after Dallmann 1999). Billefjorden fault zone, BFZ; Lomfjorden-Argardbukta fault zone, LAFZ.

Fig. 2. Summary of the Permian and Triassic lithostratigraphy of Svalbard. Adapted from Dallmann (1999), Samuelsberg \& Pickard (1999), Mørk, Dallmann et al. (1999) and Hounslow, Hu, Mørk, Vigran et al. (2007).

Fig. 3. (a) Late Carboniferous-Early Jurassic apparent polar wander path for stable Europe in 10 My increments (white dots) starting from 300 Mya (Torsvik \& Cocks 2005), and palaeomagnetic poles isolated from the Permian and Triassic rocks of Spitsbergen. Pole number is the ID number in Table 1 . The $95 \%$ confidence interval is shaded for the Permian poles, and Triassic poles have a thicker line defining the confidence cone. The timescale used is that in the palaeomagnetic database (see Table 1). (b) Palaeogeographic reconstructions of continents in the early Permian (after Van der Voo \& Torsvik 2004). The location of Spitsbergen is shown according to the dipole model of the palaeomagnetic data at $27^{\circ} \mathrm{N}$, and the octapole field model at $35^{\circ} \mathrm{N}$.

Fig. 4. Natural remanent magnetization (NRM) intensity and susceptibility properties of the Triassic of central Spitsbergen, subdivided according to formation and lithology. Data are from (a) Hounslow, Hu, Mørk, Vigran et al. (2007) and Hounslow, Hu, Mørk, Weitschat et al. (2007); (b) Hounslow, Hu, Mørk, Vigran et al. (2007) and Hounslow et al. (2008a) and (c) Hounslow et al. (2008a) and Hounslow et al. (2008b), but are presented in a different format. 
Fig. 5. (a) Isothermal remanent magnetization (IRM) acquisition curves of partly and totally remagnetized Permian samples from the Trygghamna section, and (b) and (c) thermal demagnetization of orthogonal-axis IRM curves prepared from the same samples (partly from Nawrocki 1999 and partly new data). K is volume specific susceptibility. The distinct blocking temperature at ca. $450{ }^{\circ} \mathrm{C}$ seen in (b) and to a less clear extent in (c) is typical of most Permian samples (Nawrocki 1999) and may be a result of titanomagnetite, a limited grain-size range of magnetite or maghaemite oxidation during heating.

Fig. 6. Percentage subdivision of specimen magnetization characteristics for the Triassic of central Spitsbergen, subdivided according to formation, and type of sample lithology. Line-fits indicate conventional principle components, fitted-line characteristic remanent magnetization (ChRM) data. Great circle fits indicate polarity interpreted according to great circle (remagnetization circle) trends (primary data in Hounslow, Hu, Mørk, Vigran et al. 2007; Hounslow et al. 2008a; Hounslow et al. 2008b, reformatted for this figure). $\mathrm{N}$ is the number of specimen data for each of the lithological categories.

Fig. 7. Palaeopoles (and A95 confidence regions) from overprint magnetizations reported from Permian and Triassic formations from Spitsbergen, together with the palaeopoles (and A95 confidence regions) from the High Arctic large igneous province (HALIP; Maher 2001) of late Mesozoic age. Apparent polar wander paths (APWP) of the European plate (Besse \& Courtillot 2002; Torsvik \& Cocks 2005) shown in grey. Most VGP poles numbered with ID as in Table 2 (some omitted for clarity). HALIP primary and overprint poles are a: Krumsiek et al. (1968); b: Halvorsen (1989); c: Briseid \& Halvorsen (1974); d: Vincenz et al. (1984); e: Jeleńska \& Vincenz (1985); f,h: Vincenz et al. (1981); g, i: Sandal \& Halvorsen (1973); and j: Halvorsen (1972). The 0 and 5 Mya APWP poles are displaced by ca. $8^{\circ}$ from the geocentric axial dipole model (i.e., +90 ), due to the well known "far-sidedness" of palaeomagnetic data (Van der Voo \& Torsvik 2004).

Fig. 8. Viscous remanence acquisition (VRM) acquired by four specimens (in laboratory Earths magnetic field), over a period of 20 days, along with the fitted line through the intensity versus log (time) relationship. The initial starting state is after alternating field demagnetization at $100 \mathrm{mT}$ (this has not entirely reduced all magnetization to zero). Values in brackets indicate the percentage of the undemagnetized NRM which acquisition at this rate, for $10 \mathrm{Ky}$, would induce in the specimens. 
Fig. 9. Global magnetostratigraphic columns for the Permian (after Gradstein et al. 2004 and Steiner 2006) and their possible correlation with the magnetostratigraphy of the Kapp Wijk, Trygghamna and Kapp Schoultz sections of Nawrocki \& Grabowski (2000). Magnetozone widths of $1 / 4$ indicate a single specimen, poorer demagnetization quality, with no adjacent data; a width of $1 / 2$ indicates a single specimen, good demagnetization quality, with no adjacent data; a width of $3 / 4$ indicates one or more adjacent specimens with poorer quality demagnetization data, of the same polarity; a full bar indicates one or more adjacent specimens with good quality demagnetization data, of the same polarity. Ticks adjacent to the left-side of polarity columns are sampling levels. Inset B shows the demagnetization paths of the four adjacent specimens from the normal magnetozone in the Hovtinden Mb. (Kapp Starostin Fm.). The round symbols in grey are the initial NRM directions. Paths marked in black had principle component line-fits determined, those in grey did not. The star marks the mean direction of the characteristic remanence of these four specimens.

Fig. 10. Summary of the Lower Triassic magnetostratigraphy and biostratigraphy from Spitsbergen. Tschermakfjellet and Trygghamna section from Nawrocki \& Grabowski (2000), re-drawn according to the magnetozone criteria in Fig. 9 and using the modern lithostratigraphy; Vikinghøgda section from Hounslow et al. (2008b); Milne Edwardsfjellet section from Hounslow et al. (2008a). The VikinghøgdaTschermakfjellet intersection magnetostratigraphic correlations are speculative and are largely dictated by the lithostratigraphy. Section locations on Fig. 1.

Fig. 11. Summary of the Middle and Upper Triassic magnetostratigraphy of central Svalbard. Milne Edwardsfjellet section (from Hounslow, Hu, Mørk, Vigran et al. 2007; Hounslow et al. 2008a); Dalsnuten section data from Hounslow, Hu, Mørk, Vigran et al. (2007). Section locations on Fig. 1. Tethys (Alps) column after Muttoni et al. (2000) and references in Hounslow et al. (2008b). Tethys (Mayerling, Stoures, Bolücektasi Tepe) from Gallet et al. (1992), Broglio Loriga et al. (1999), Gallet et al. (1994) as compiled in Hounslow, Hu, Mørk, Vigran et al. (2007). 


\begin{tabular}{|c|c|c|c|c|c|c|c|c|c|c|c|}
\hline \multirow[b]{2}{*}{ Formation/Mb./Unit } & \multirow[b]{2}{*}{ Location } & \multicolumn{5}{|c|}{ Fisher Mean } & \multicolumn{2}{|c|}{ VGP } & \multirow[b]{2}{*}{ Ref. $^{g}$} & \multirow[b]{2}{*}{ ID $^{\mathrm{h}}$} & \multirow{2}{*}{$\begin{array}{c}\text { APWP } \\
\text { "fit-age" }\end{array}$} \\
\hline & & Dec. & Inc. & $\mathbf{k}^{\mathbf{a}}$ & $\alpha_{95}^{b}$ & $\mathbf{N l}^{\mathrm{c}} / \mathbf{N p}^{\mathrm{d}}$ & Lat. $^{\mathrm{e}}$ & Long. & & & \\
\hline De Geerdalen Fm. ${ }^{j}$ & Dalsnuten & 66 & 71 & 24.4 & 3.1 & $63 / 27$ & 59 & 113 & 1 & 15 & 203 \\
\hline Tschermakfjellet Fm. ${ }^{j}$ & Dalsnuten & 66 & 68 & 46.3 & 4.1 & $27 / 0$ & 54 & 117 & 1 & 14 & 210 \\
\hline Top Botneheia Fm. & Milne Edwardsfjellet & 50 & 68 & 125 & 4.3 & $10 / 0$ & 57 & 134 & 1 & 13 & 223 \\
\hline Botneheia Fm. & Milne Edwardsfjellet & 45 & 62 & 31.3 & 3.7 & $48 / 0$ & 50 & 143 & 2 & 12 & 235 \\
\hline Vendomdalen $\mathrm{Mb}$. & Milne Edwardsfjellet & 36 & 60 & 36.3 & 5 & $24 / 0$ & 50 & 154 & 2 & 11 & 265 \\
\hline Vendomdalen $\mathrm{Mb}$. & Vikinghøgda & 42 & 66 & 42.4 & 3.3 & $40 / 6$ & 57 & 143 & 3 & 10 & 235 \\
\hline Lusitaniadalen $\mathrm{Mb}$. & Vikinghøgda & 26 & 64 & 24.5 & 3.2 & $28 / 53$ & 56 & 163 & 3 & 9 & 260 \\
\hline Deltadalen $\mathrm{Mb} .^{\mathrm{k}}$ & Vikinghøgda & 31 & 61 & 20.1 & 3.4 & $35 / 53$ & 50 & 159 & 3 & 8 & 268 \\
\hline Vardebukta Fm. & Trygghamna & 191 & -55 & 39.3 & 8.9 & $8 / 0$ & 48 & 182 & 4 & 7 & $280\{7.8 / 10.3)$ \\
\hline & & & & & 14 & & 31 & 140 & & 6 & \\
\hline Templefjorden Grp. & Trygghamna & 209 & -45 & 8.6 & 17 & $10 / 0$ & 37 & 162 & 4 & 5 & 292 \\
\hline Upper Kapp Starostin Fm. & Festningen/Bellsund & 47 & 36 & 12 & 10.5 & $117 / 0$ & 28 & 143 & 6 & 4 & 292 \\
\hline Lower Kapp Starostin Fm. & Festningen/Bellsund & 41 & 57 & 233 & 8.1 & $19 / 0$ & 64 & 146 & 6 & 3 & $243\{7.0 / 7.8\}$ \\
\hline Wordiekammen Fm. & Festningen/Bellsund & 56 & 43 & 12.9 & 22.3 & $40 / 0$ & 31 & 132 & 6 & 2 & $230\{11 / 25\}$ \\
\hline Gipsdalen Grp. & Kapp Schoultz & 199 & -45 & 19.1 & 7.6 & $16 / 0$ & 38 & 171 & 4 & 1 & 300 \\
\hline \multicolumn{12}{|c|}{$\begin{array}{l}\text { a Fisher precision parameter. } \\
\text { b Fisher } 95 \% \text { cone of confidence. } \\
\text { c Number of specimens with fitted lines used in determining the mean direction. } \\
\text { d Number of specimens with great circle planes used in determining the mean direction. } \\
\text { e, f The latitude and longitude of the mean virtual geomagnetic pole. } \\
\text { g References 1: Hounslow, Hu, Mørk, Vigran et al. (2007); 2: Hounslow et al. (2008a); 3: Hounslow et al. (2008b); 4: Nawrocki (1999); 5: } \\
\text { Jeleńska (1987); 6: Jeleńska \& Vincenz (1985). } \\
\text { he Pole number in Fig. } 3 \text {. } \\
\text { he } \\
\text { i APWP fit-age is the closest age match (in My) to the Baltica APWP of Torsvik \& Cocks (2005). Only those flagged with }\{\gamma c / \gamma o\} \text { are } \\
\text { significantly different (at the } 95 \% \text { confidence level) to the APWP path using the comparison statistics of McFadden \& McElhinney (1990), } \\
\gamma \text { c being the critical angle and } \gamma \text { o the observed angular divergence. } \\
\text { jerobably vertically rotated on Palaeogene age decollément. }\end{array}$} \\
\hline
\end{tabular}


Table 1. Summary of the mean palaeomagnetic pole data for the Permian and Triassic of Spitsbergen. The age boundaries used by Torsvik \& Cocks (2005) and the palaeomagnetic database are 290 Mya for the Carboniferous/Permian, 251 Mya for the Permian/Triassic and 206 Mya for the Triassic/Jurassic boundaries 


\begin{tabular}{|c|c|c|c|c|c|c|c|c|c|c|}
\hline & & \multicolumn{5}{|c|}{ Fisher Mean } & \multicolumn{2}{|c|}{ VGP } & \multirow[b]{2}{*}{ Ref. } & \multirow[b]{2}{*}{ ID $^{9}$} \\
\hline Formation/Mb. (polarity) & Location & Dec. & Inc. & $\mathbf{k}^{\mathbf{a}}$ & $\alpha_{95}^{b}$ & $\mathrm{Nl}^{\mathrm{c}}$ & Lat. $^{\text {d }}$ & Long. & & \\
\hline De Geerdalen/Tsc. Fms. (R) & Dalsnuten & 306 & 84 & 4.2 & 22.6 & 34 & 79 & 309 & 1 & 16 \\
\hline De Geerdalen/Tsc. Fms. (N) & Dalsnuten & 8 & 84 & 11.8 & 5.5 & 62 & 88 & 92 & 1 & 15 \\
\hline top most Botneheia Fm. (N) & Milne Edwardsfjellet & 36 & 82 & 66 & 6 & 10 & 81 & 114 & 1 & 14 \\
\hline Botneheia Fm (R) & Milne Edwardsfjellet & 203 & 78 & 8.6 & 5.2 & 98 & 56 & 2 & 2 & 13 \\
\hline Botneheia Fm (N) & Milne Edwardsfjellet & 17 & 83 & 22 & 3.3 & 86 & 86 & 127 & 2 & 12 \\
\hline Vendomdalen $\mathrm{Mb}$. (R) & Milne Edwardsfjellet & 270 & 75 & 7.3 & 12.1 & 23 & 60 & 309 & 2 & 11 \\
\hline Vendomdalen $\mathrm{Mb} .(\mathrm{N})$ & Milne Edwardsfjellet & 8 & 81 & 23.3 & 4.7 & 41 & 84 & 175 & 2 & 10 \\
\hline Vendomdalen $\mathrm{Mb} .(\mathrm{R}+\mathrm{N})$ & Vikinghøgda & 296 & 68 & 13.8 & 9.4 & 19 & 55 & 276 & 3 & 9 \\
\hline Vendomdalen $\mathrm{Mb} .(\mathrm{N})$ & Vikinghøgda & 303 & 73 & 16.2 & 10.2 & 15 & 63 & 273 & 3 & 8 \\
\hline Lusitaniadalen Mb. (R) & Vikinghøgda & 232 & 85 & 9.2 & 5.8 & 50 & 71 & 353 & 3 & 7 \\
\hline Lusitaniadalen $\mathrm{Mb}$. (N) & Vikinghøgda & 15 & 84 & 14.3 & 4.5 & 73 & 87 & 102 & 3 & 6 \\
\hline Deltadalen Mb. (R) & Vikinghøgda & 329 & 76 & 5.8 & 9 & 52 & 73 & 247 & 3 & 5 \\
\hline Deltadalen Mb. (N) & Vikinghøgda & 57 & 85 & 13.4 & 7.3 & 31 & 80 & 70 & 3 & 4 \\
\hline Kapp Starostin Fm. (N) & Kapp Schoultz & 30 & 81 & 49.9 & 3.1 & 42 & 80 & 132 & 4 & 3 \\
\hline Kapp Starostin Fm. $(\mathrm{N})^{\mathrm{h}}$ & Kapp Schoultz & 343 & 80 & 46.4 & 3.3 & 42 & 82 & 240 & 4 & \\
\hline Kapp Starostin Fm. (N) & Trygghamna & 52 & -3 & 30.5 & 8.9 & 10 & & & 4 & 2 \\
\hline Kapp Starostin Fm. $(\mathrm{N})^{\mathrm{h}}$ & Trygghamna & 0 & 78 & 48.2 & 7 & 10 & 79 & 199 & 4 & \\
\hline Kapp Starostin Fm. (R) & Trygghamna & 239 & -3 & 23.2 & 16.2 & 5 & & & 4 & 1 \\
\hline Kapp Starostin Fm. (R $)^{\mathrm{h}}$ & Trygghamna & 183 & -77 & 76.4 & 8.8 & 5 & 78 & 193 & 4 & \\
\hline \multicolumn{11}{|c|}{$\begin{array}{l}{ }^{a} \text { Fisher precision parameter. } \\
\text { b Fisher } 95 \% \text { cone of confidence. } \\
{ }^{c} \text { Number of specimens with fitted lines used in determining the mean direction. } \\
\text { d, } \text { The latitude and longitude of the mean virtual geomagnetic pole. } \\
{ }^{f} \text { References as given in Table } 1 . \\
{ }^{g} \text { Pole number in Fig. } 7 \text {. } \\
\text { h Overlying result after bedding correction. }\end{array}$} \\
\hline
\end{tabular}

Table 2. Summary of the mean directions for overprints from the Permian and Triassic of Spitsbergen (prior to bedding correction). 
Fig. 1.

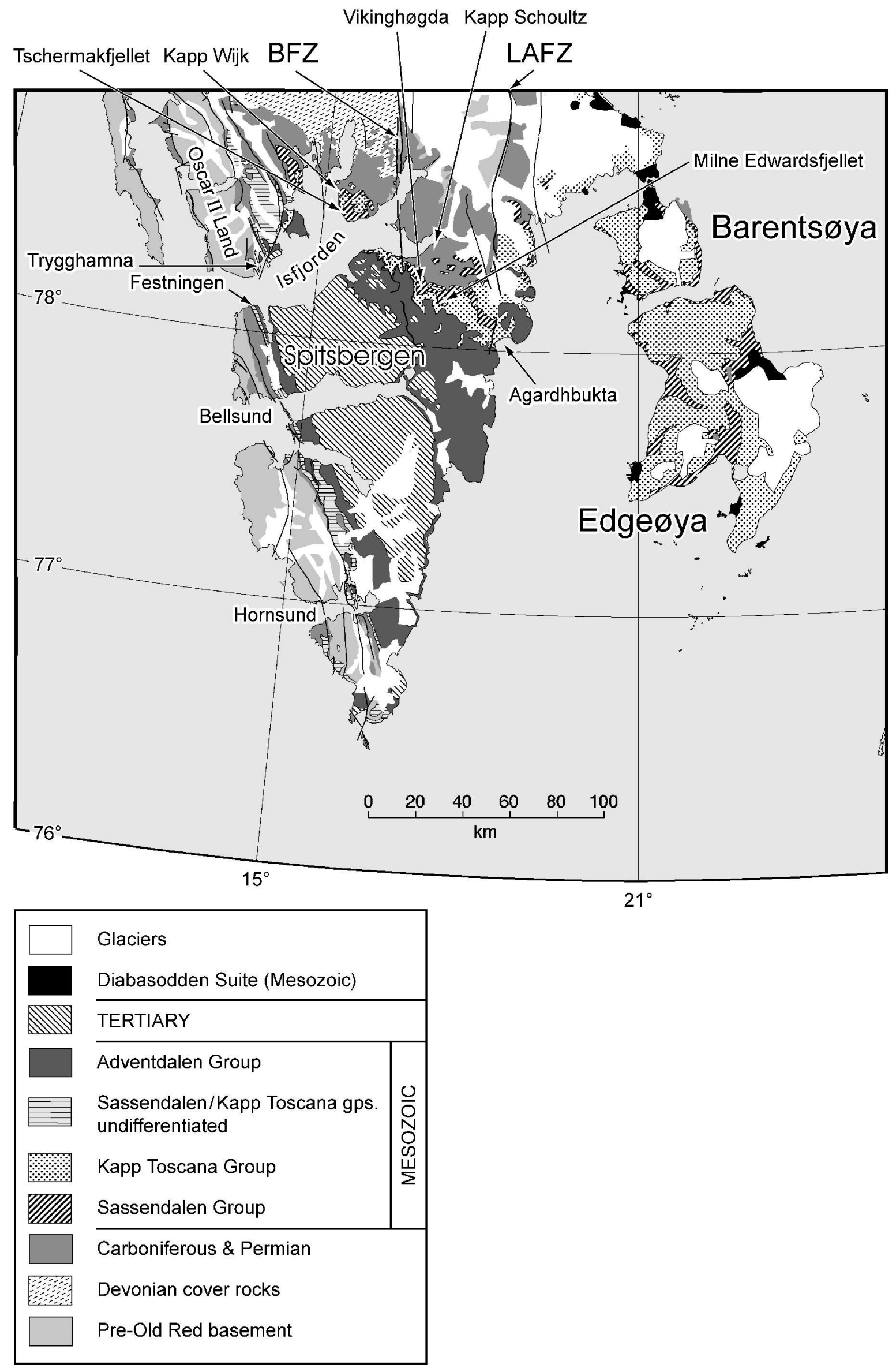




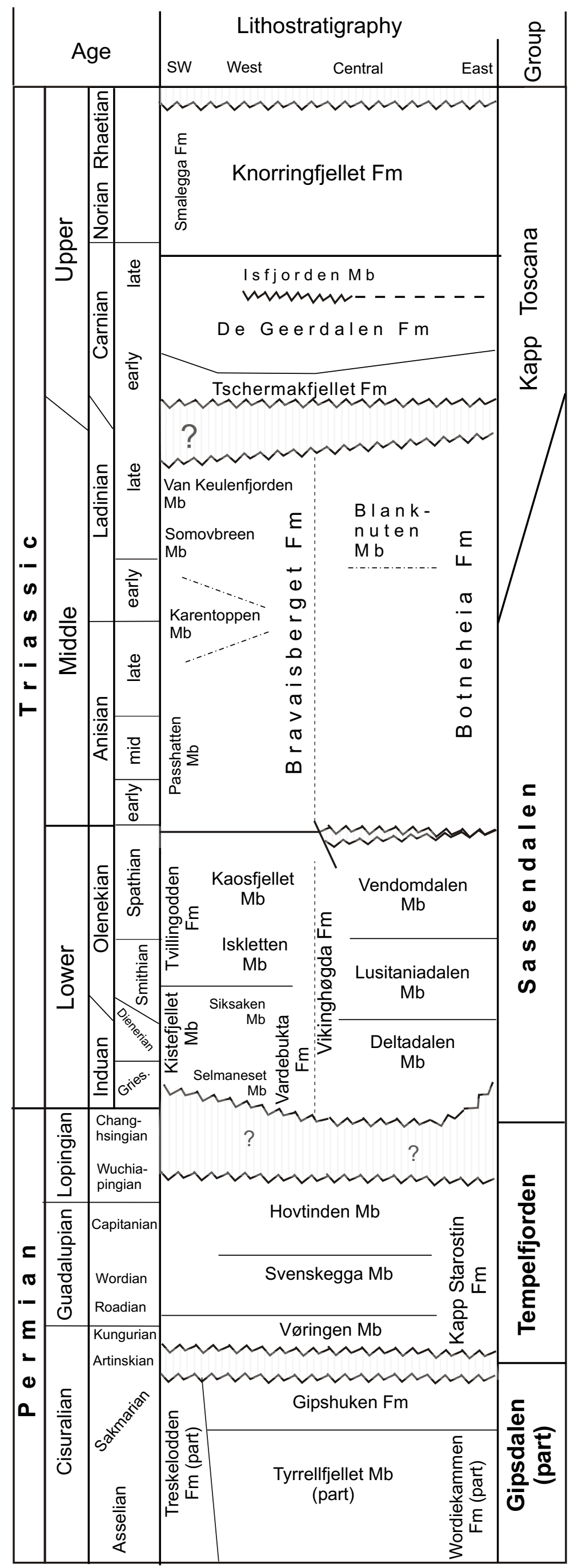



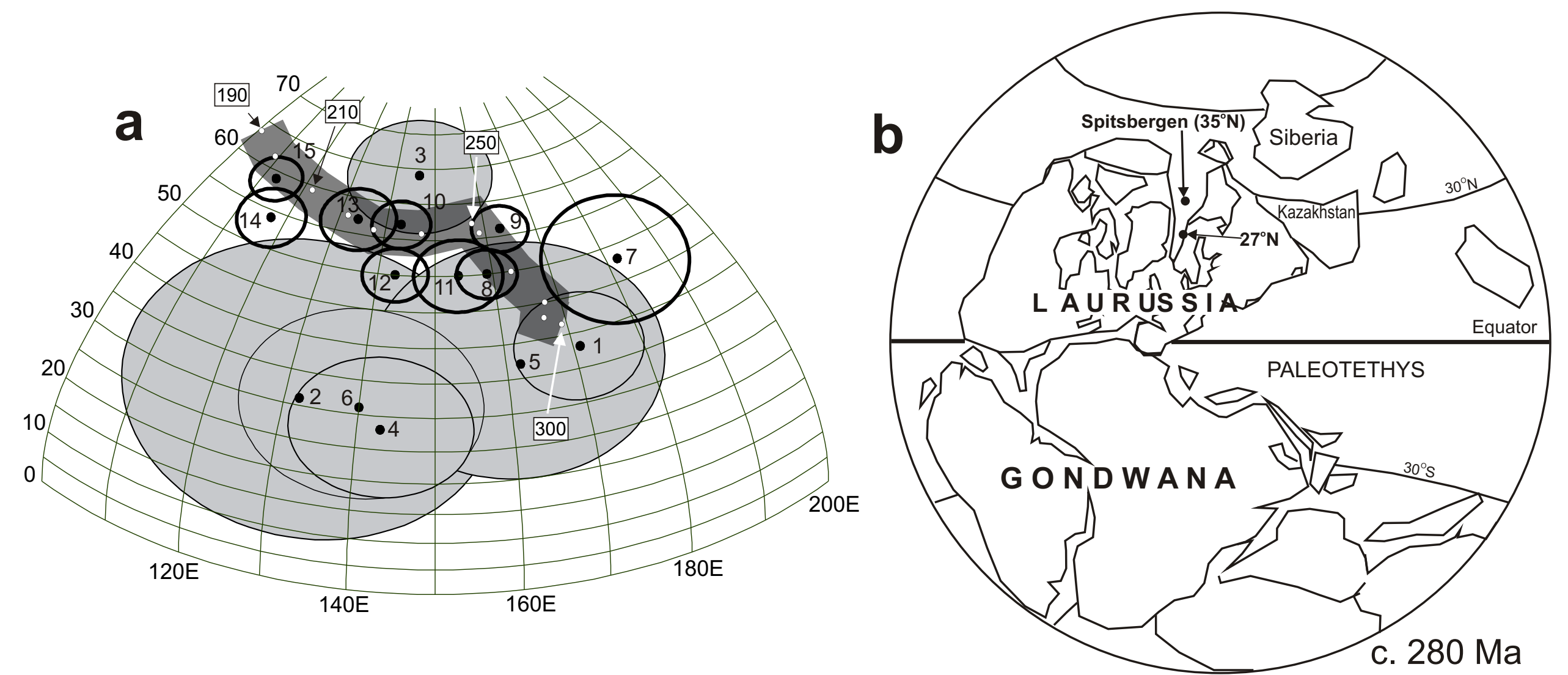

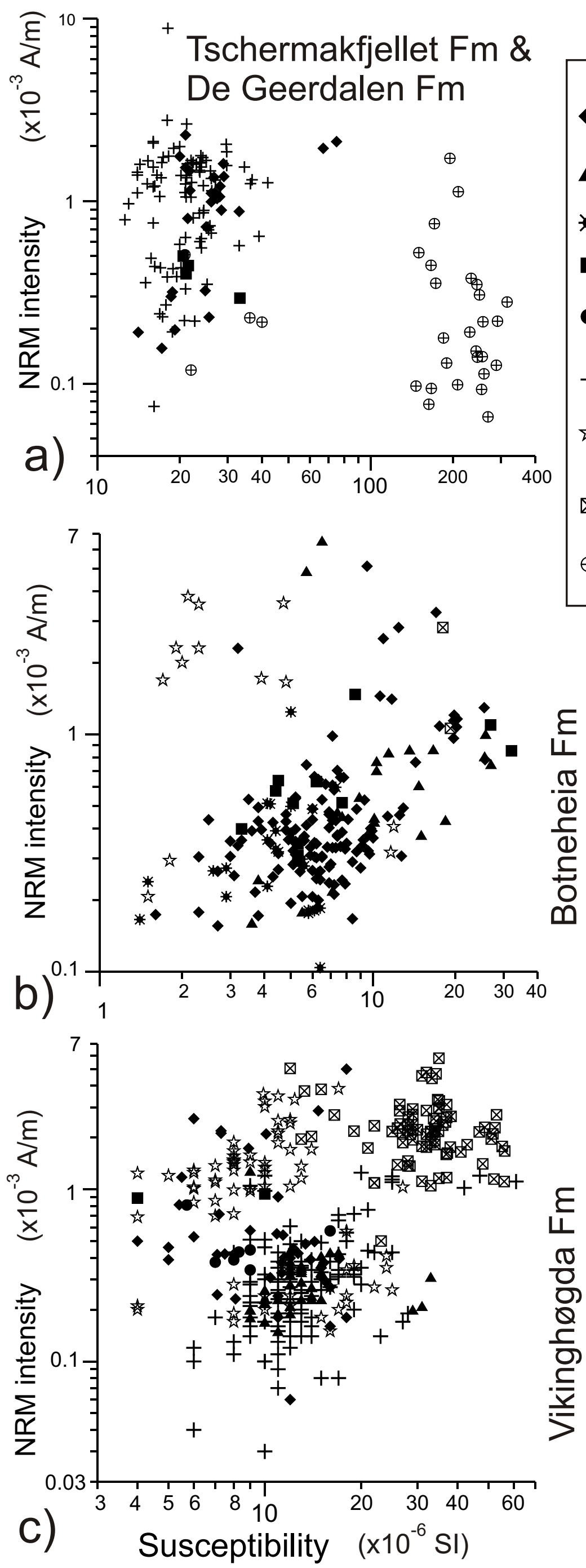


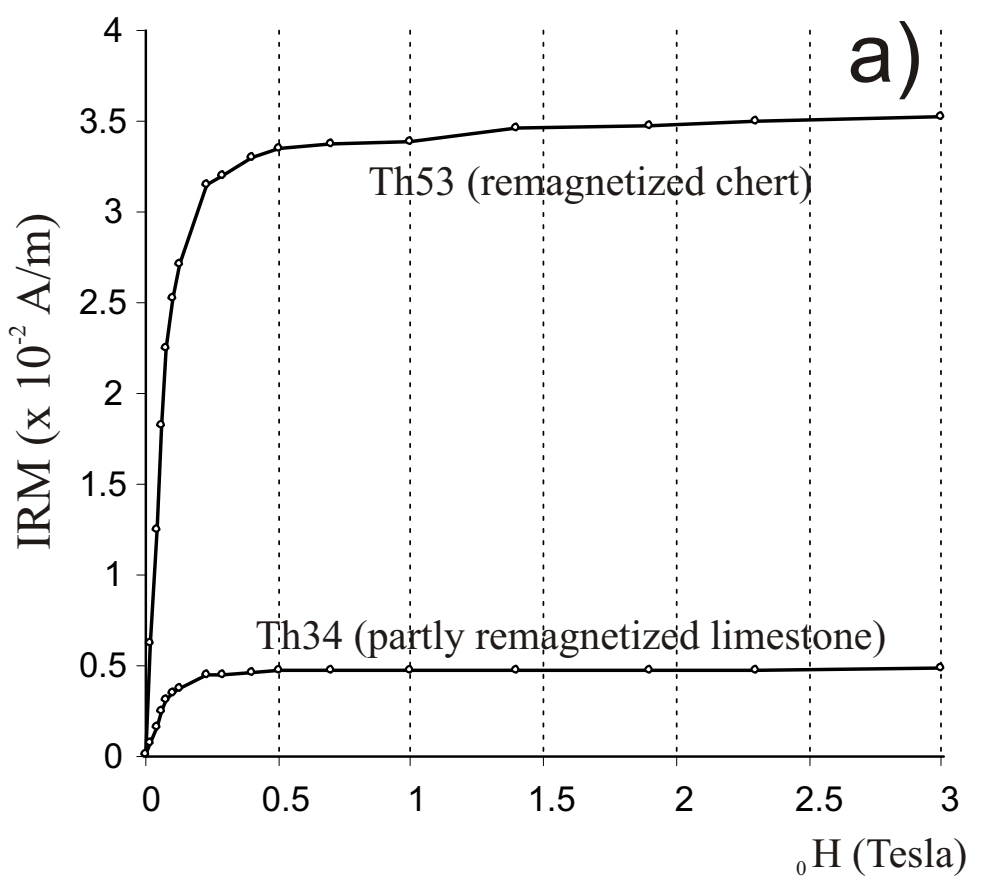

Fig. 5 .
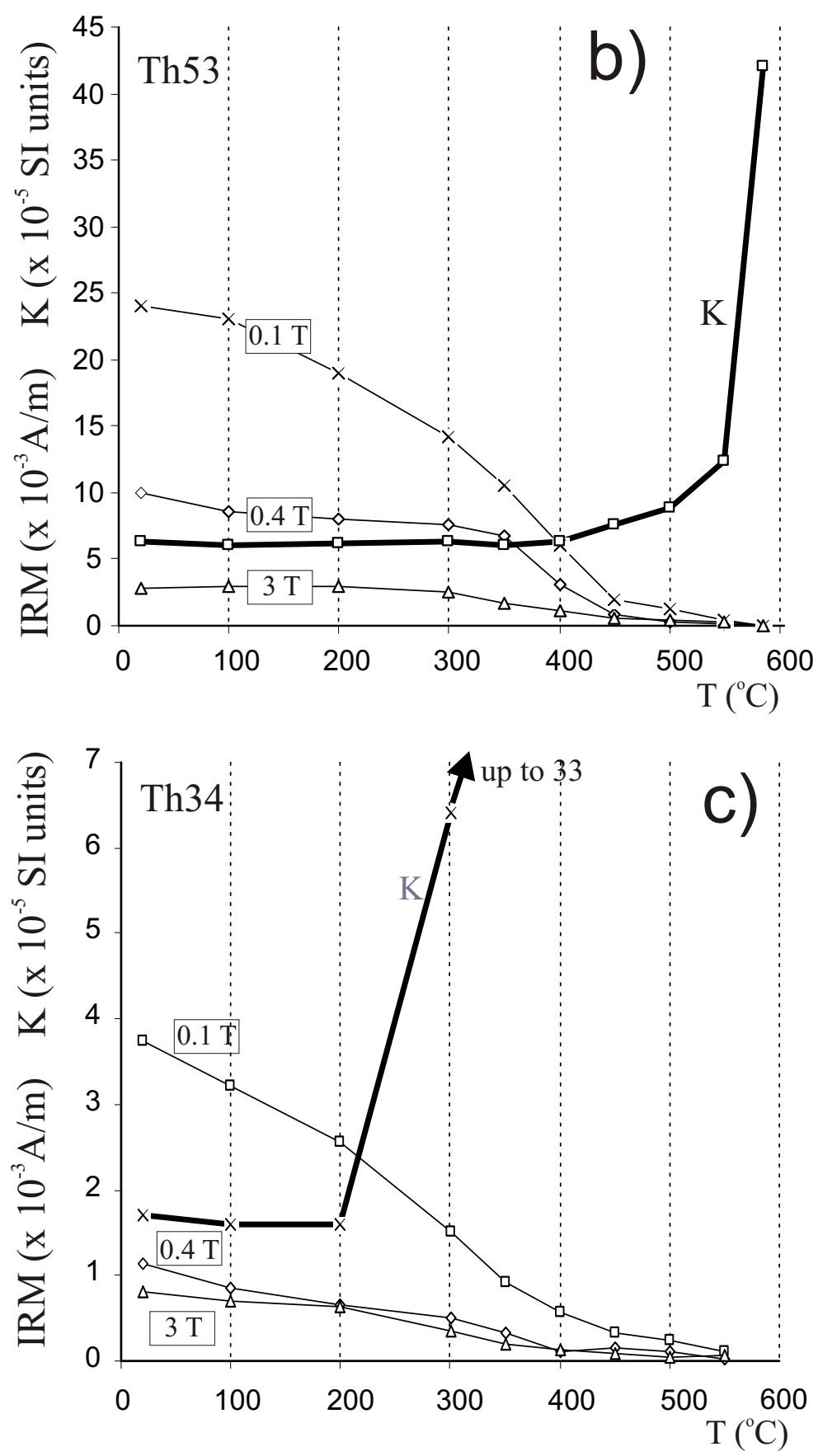


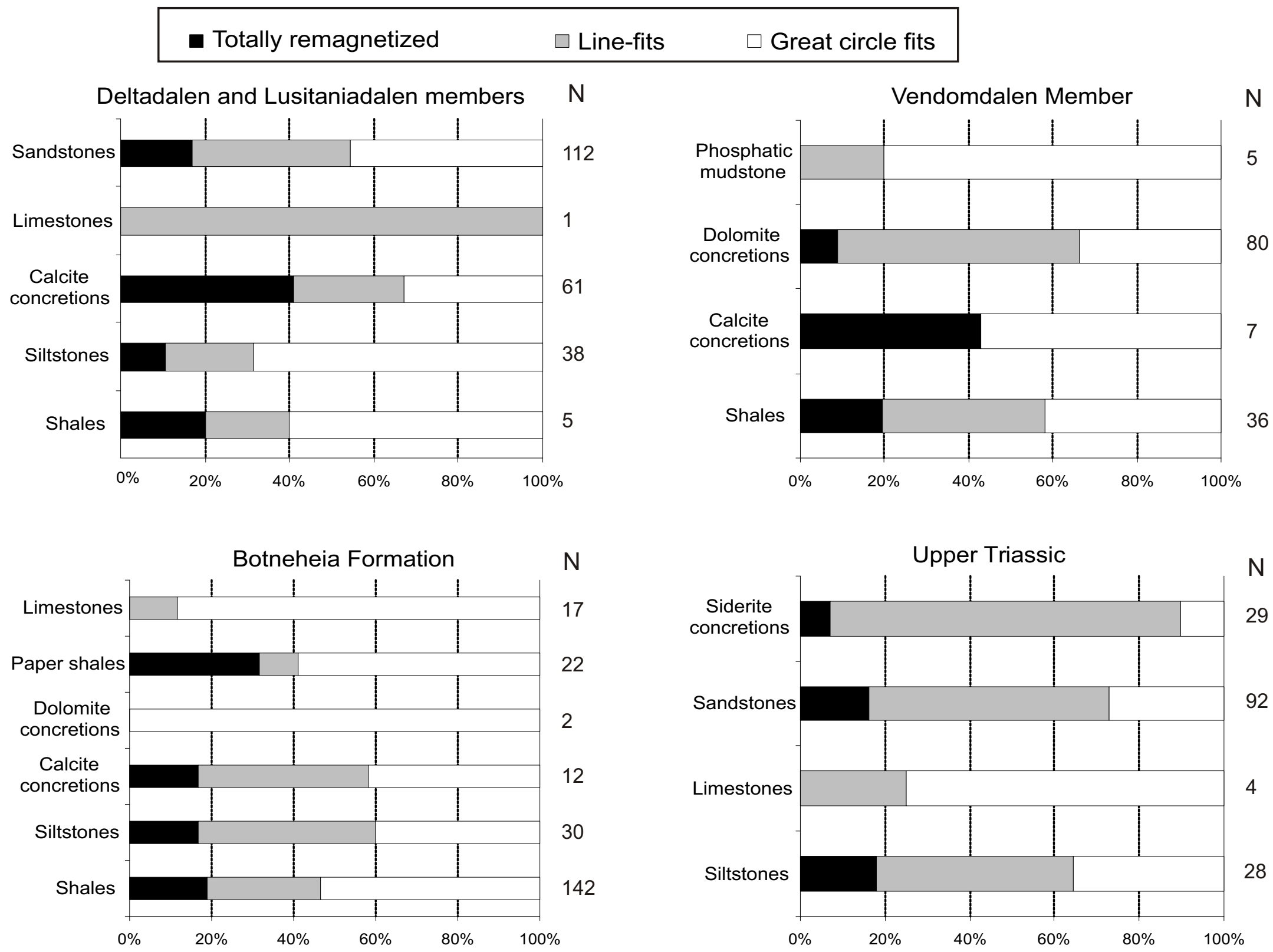

Fig. 6. 


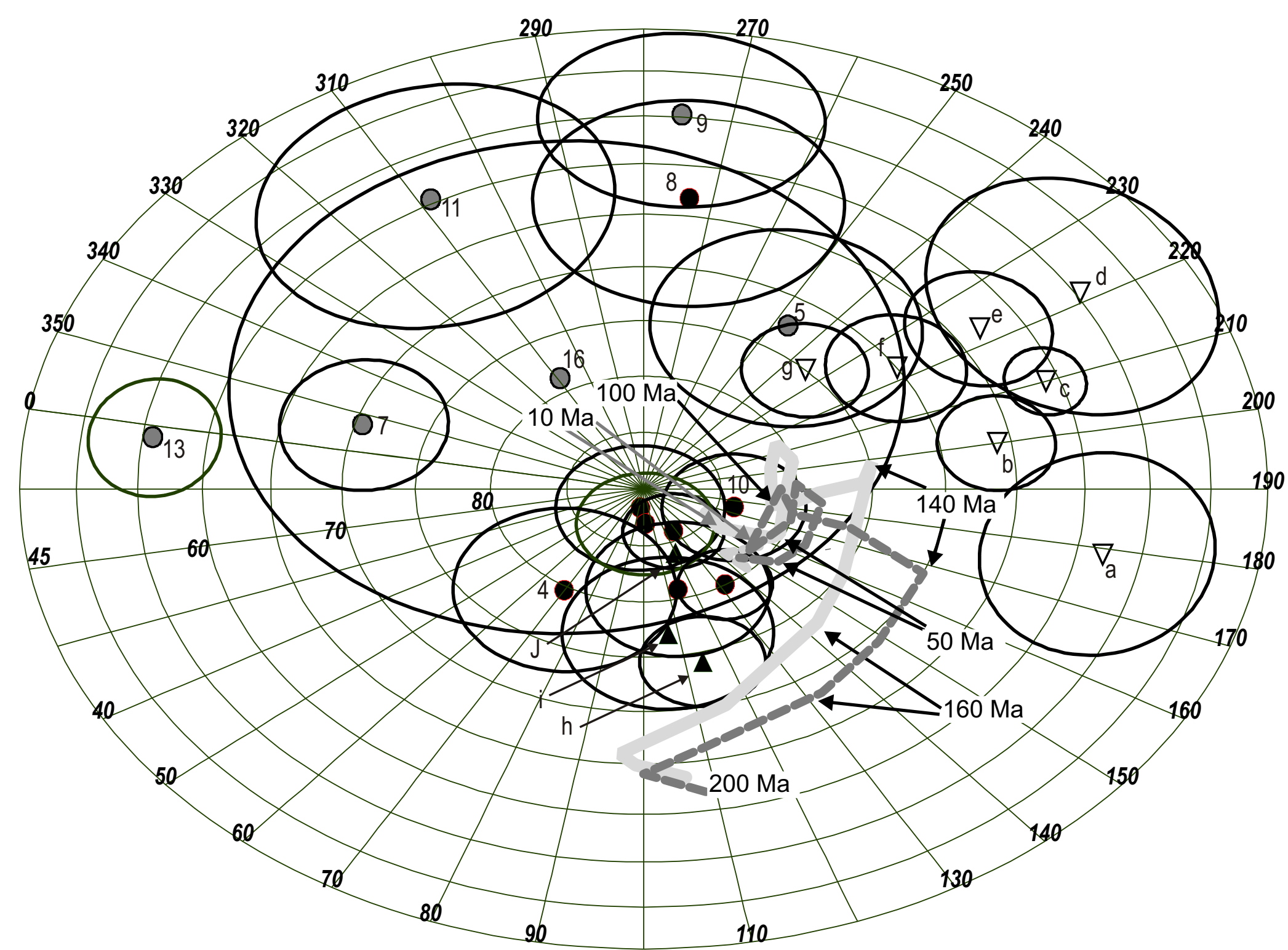

Fig. 7.

$\nabla \quad$ HALIP primary directions

\ HALIP overprints
O Permian \& Triassic overprints (reverse primary polarity)

- Permian \& Triassic overprints (normal primary polarity)

Mean European path (Besse \& Courtillot 2002)

Mean European path (Torsvik \& Cocks 2005) 


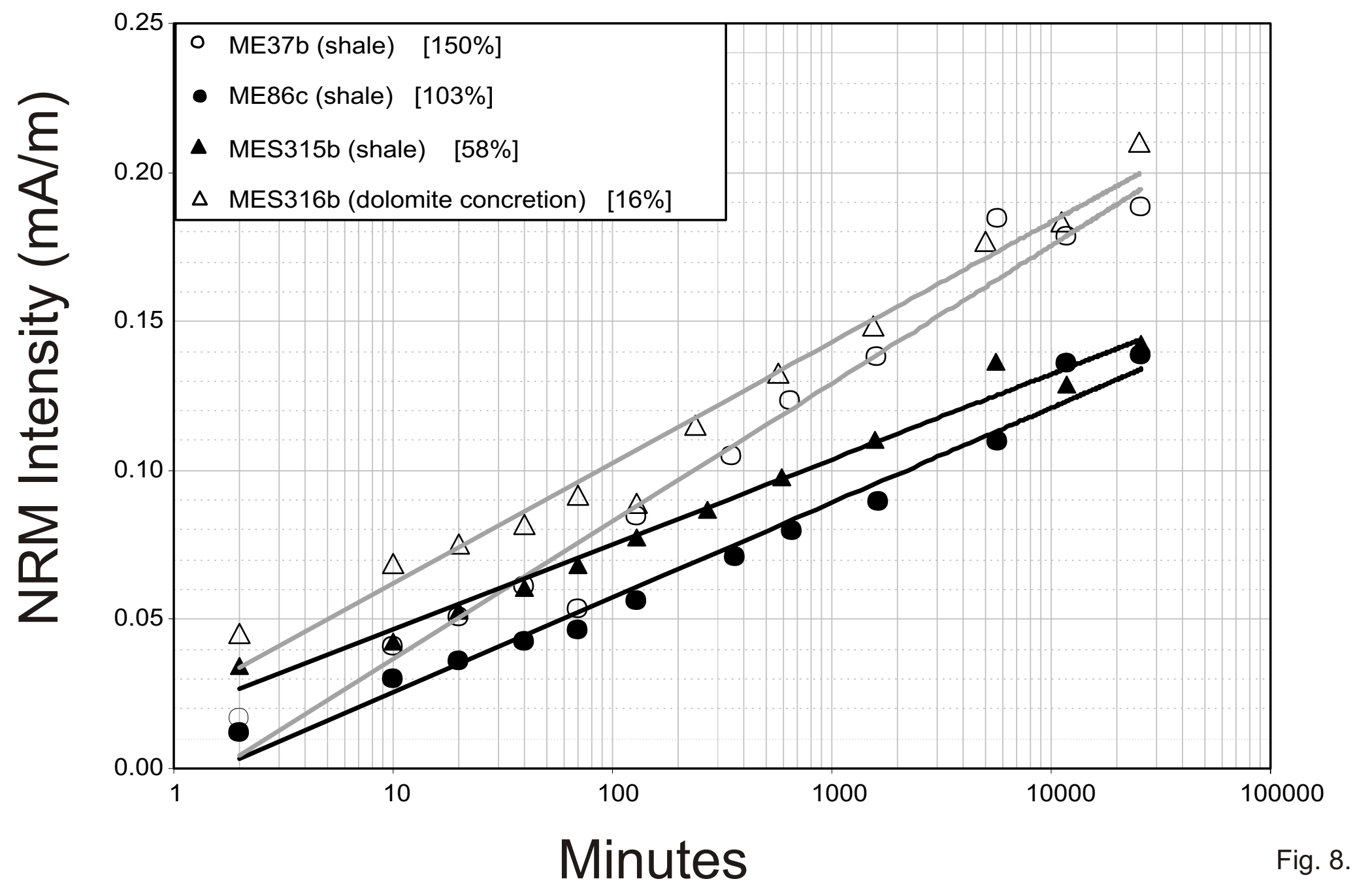




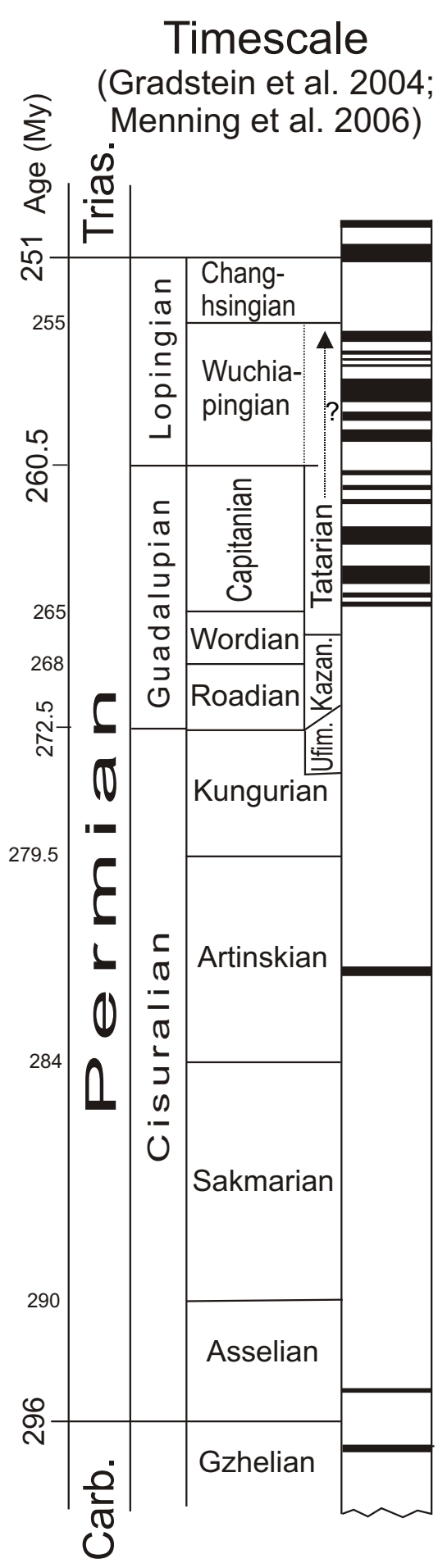

Kapp Wijk

Vikinghøgda Fm

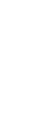

E60

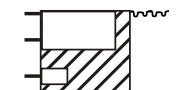

4

है

'Chang-N'

'Capitan-N'
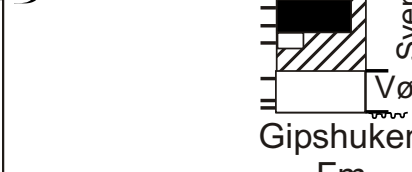

$\mathrm{Fm}$

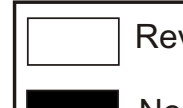

Reversed polarity

Normal polarity

VII No or uncertain data

Magnetostratigraphic correlation

Trygghamna

Steiner (2006)

timescale

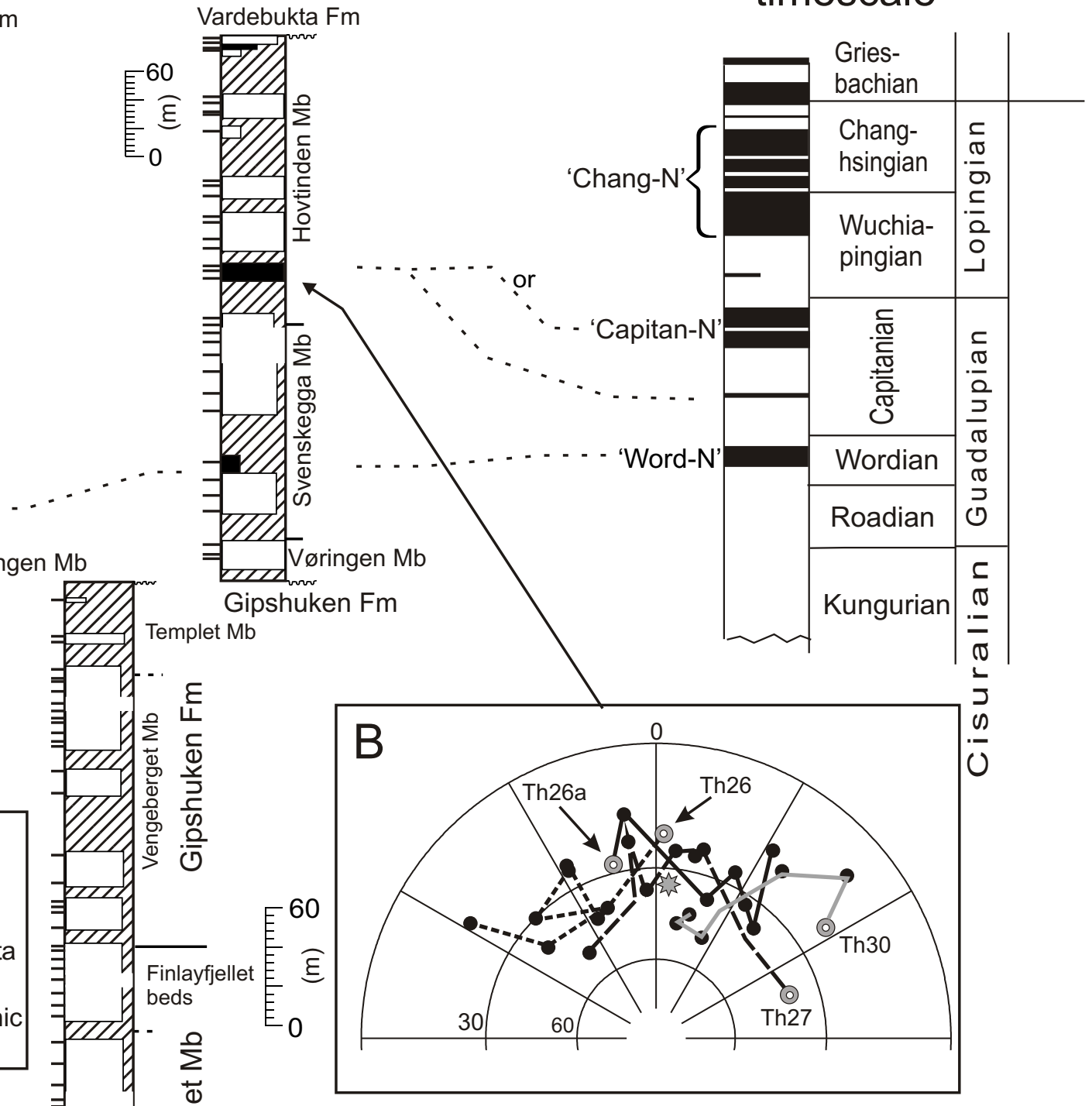

Fig. 9. 


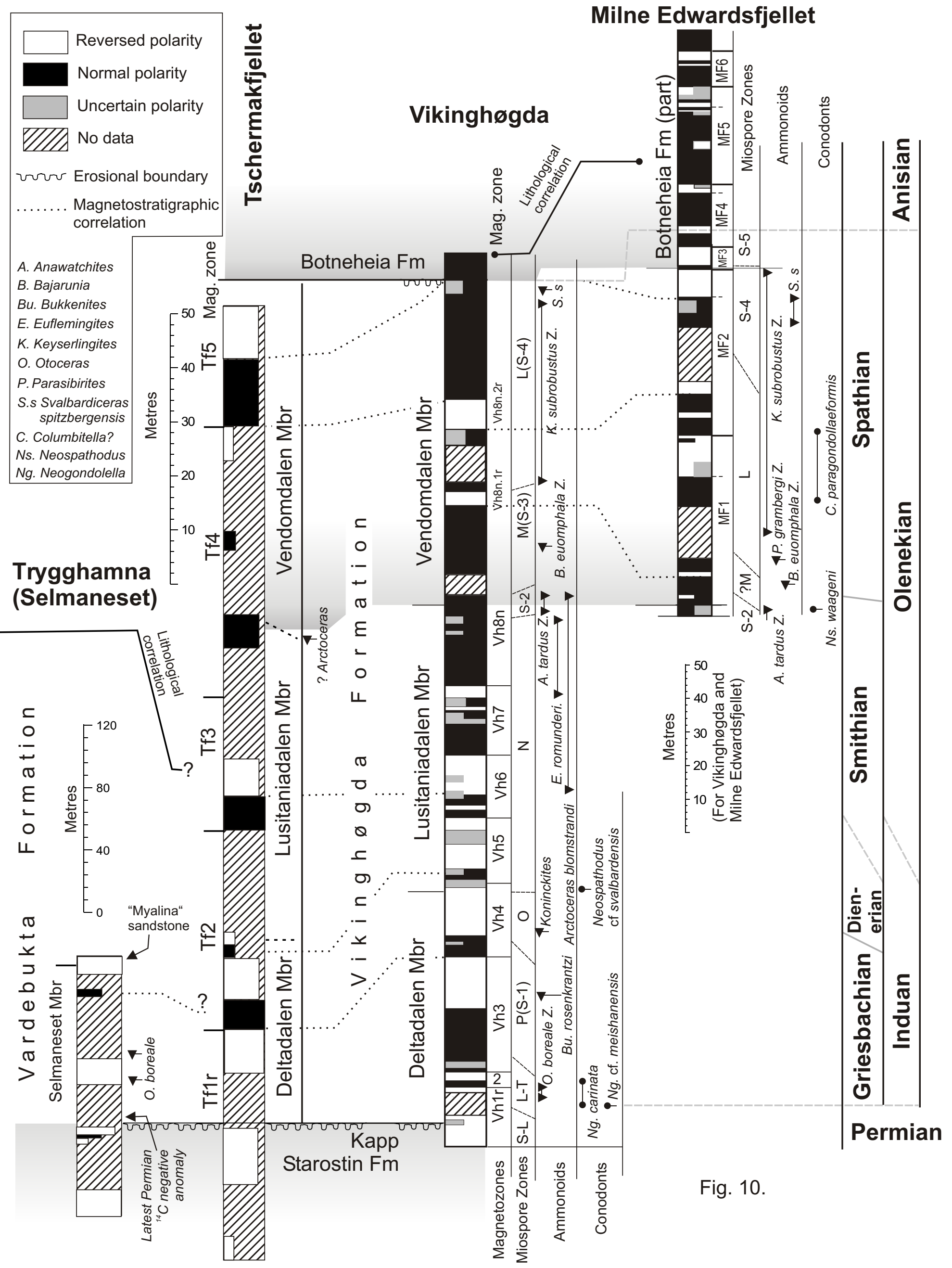




\section{Milne Edwardsfjellet (Spitsbergen)}

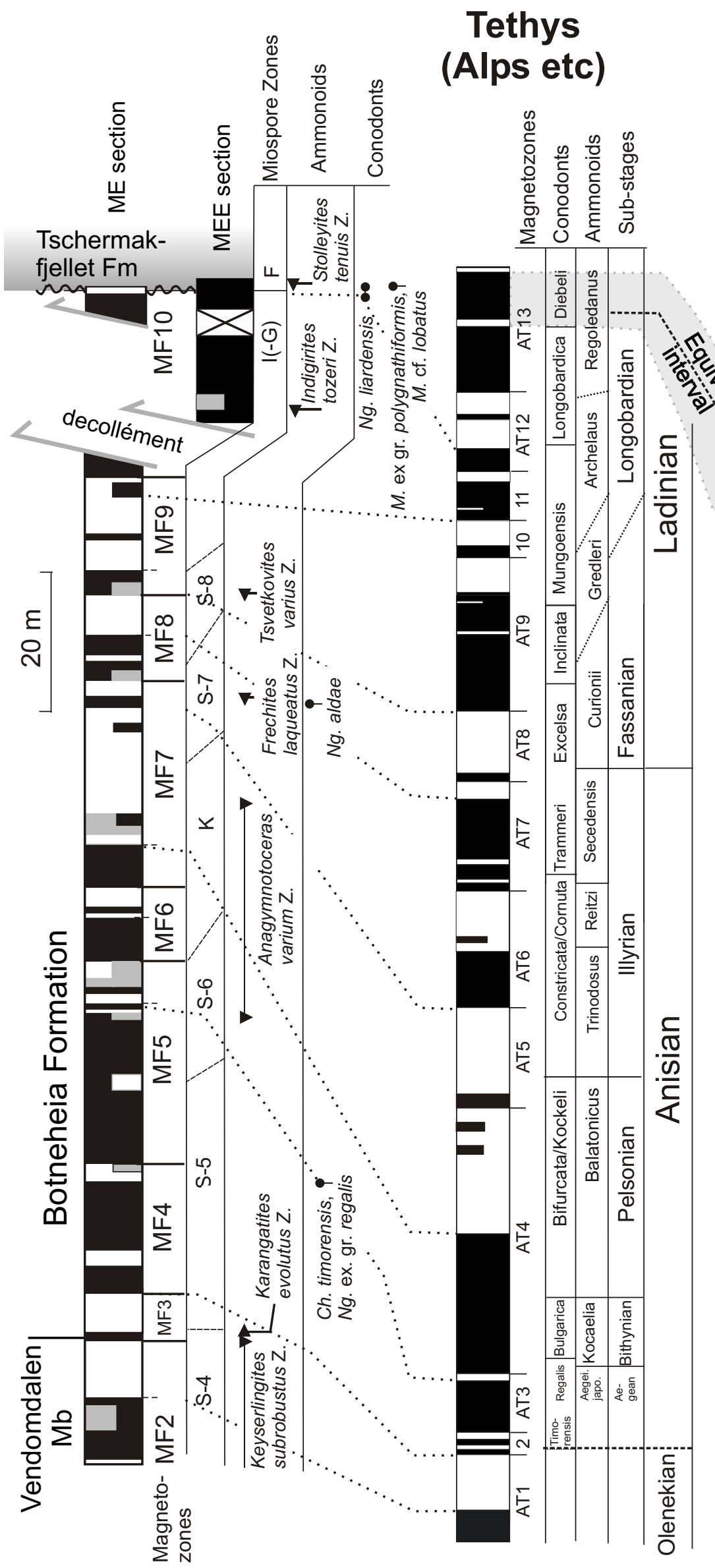

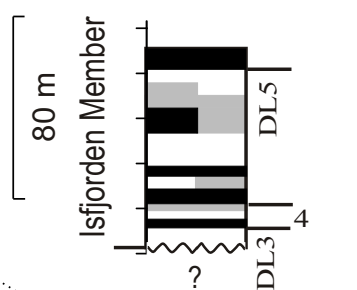
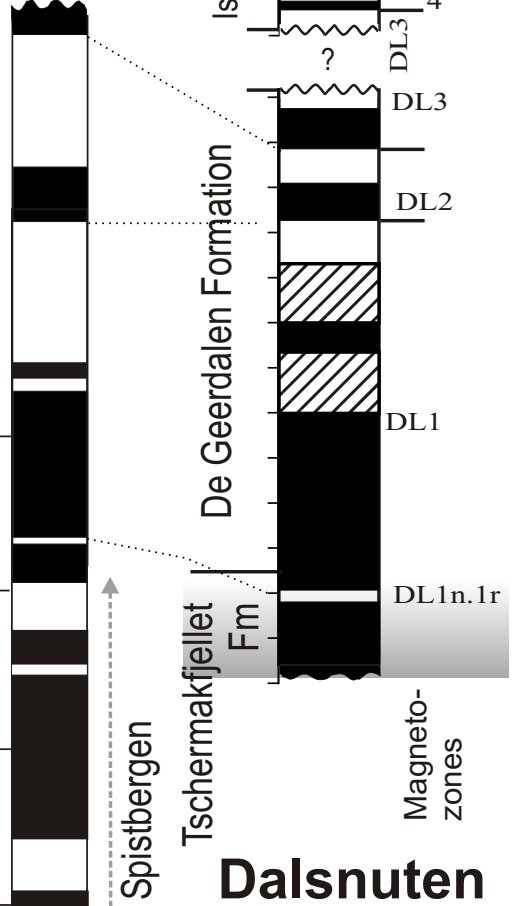

(Spitsbergen)

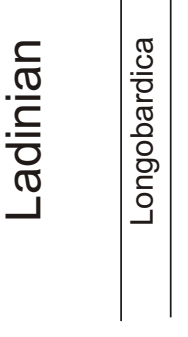

\section{Tethys \\ (Mayerling, Stoures \& Bolücektasi Tepe sections)}

\begin{tabular}{|l|}
\hline$\rightarrow$ Ladinian/Carnian \\
boundary at Stoures
\end{tabular}

Fig. 11 